\title{
Two decades of inorganic carbon dynamics along the West Antarctic Peninsula
}

\author{
C. Hauri ${ }^{1,2}$, S. C. Doney ${ }^{3}$, T. Takahashi ${ }^{4}$, M. Erickson ${ }^{5}$, G. Jiang ${ }^{6}$, and H. W. Ducklow ${ }^{4}$ \\ ${ }^{1}$ International Pacific Research Center, SOEST, University of Hawai'i, Honolulu, HI, USA \\ ${ }^{2}$ International Arctic Research Center, University of Alaska Fairbanks, Fairbanks, AK, USA \\ ${ }^{3}$ Marine Chemistry and Geochemistry Department, Woods Hole Oceanographic Institution, Woods Hole, MA, USA \\ ${ }^{4}$ Lamont-Doherty Earth Observatory, Columbia University, Palisades, NY, USA \\ ${ }^{5}$ Antarctic Support Contractor, Arlington, VA, USA \\ ${ }^{6}$ School of Earth Sciences, University of Melbourne, Melbourne, VIC, Australia
}

Correspondence to: C. Hauri (chauri@alaska.edu)

Received: 17 April 2015 - Published in Biogeosciences Discuss.: 7 May 2015

Revised: 21 September 2015 - Accepted: 28 October 2015 - Published: 26 November 2015

\begin{abstract}
We present 20 years of seawater inorganic carbon measurements collected along the western shelf and slope of the Antarctic Peninsula. Water column observations from summertime cruises and seasonal surface underway $p \mathrm{CO}_{2}$ measurements provide unique insights into the spatial, seasonal, and interannual variability in this dynamic system. Discrete measurements from depths $>2000 \mathrm{~m}$ align well with World Ocean Circulation Experiment observations across the time series and underline the consistency of the data set. Surface total alkalinity and dissolved inorganic carbon data showed large spatial gradients, with a concomitant wide range of $\Omega_{\text {arag }}$ ( $<1$ up to 3.9 ). This spatial variability was mainly driven by increasing influence of biological productivity towards the southern end of the sampling grid and meltwater input along the coast towards the northern end. Large inorganic carbon drawdown through biological production in summer caused high near-shore $\Omega_{\text {arag }}$ despite glacial and seaice meltwater input. In support of previous studies, we observed Redfield behavior of regional C / N nutrient utilization, while the C / P $(80.5 \pm 2.5)$ and N / P (11.7 \pm 0.3$)$ molar ratios were significantly lower than the Redfield elemental stoichiometric values. Seasonal salinity-based predictions of $\Omega_{\text {arag }}$ suggest that surface waters remained mostly supersaturated with regard to aragonite throughout the study. However, more than $20 \%$ of the predictions for winters and springs between 1999 and 2013 resulted in $\Omega_{\text {arag }}<1.2$. Such low levels of $\Omega_{\text {arag }}$ may have implications for important organisms such as pteropods. Even though we did not detect any statis-
\end{abstract}

tically significant long-term trends, the combination of ongoing ocean acidification and freshwater input may soon induce more unfavorable conditions than the ecosystem experiences today.

\section{Introduction}

Antarctic continental shelves are viewed as strong anthropogenic $\mathrm{CO}_{2}$ sinks and therefore play an important role in global biogeochemical cycles (Arrigo et al., 2008). These highly productive regions also support ecosystems that are exposed to rapid environmental change (Ducklow et al., 2007, 2012). Conditions along the western shelf of the Antarctic Peninsula (WAP, Fig. 1) are characterized by rapid ocean-atmosphere warming, sea-ice retreat and melting of glaciers (Ducklow et al., 2012; Stammerjohn et al., 2012; Meredith et al., 2013), impacting phytoplankton concentrations (Montes-Hugo et al., 2009) and higher trophic level organisms such as krill, fish, and Adèlie penguins (Ducklow et al., 2007, 2012; Schofield et al., 2010). Climate and oceanographic trends are also mirrored in the inorganic carbon dynamics, which could feed back to global carbon cycling and/or enhance the projected fast progression of Southern Ocean acidification (McNeil and Matear, 2008; Steinacher et al., 2009; Bopp et al., 2013), thereby imposing additional environmental stressors on the ecosystem. 


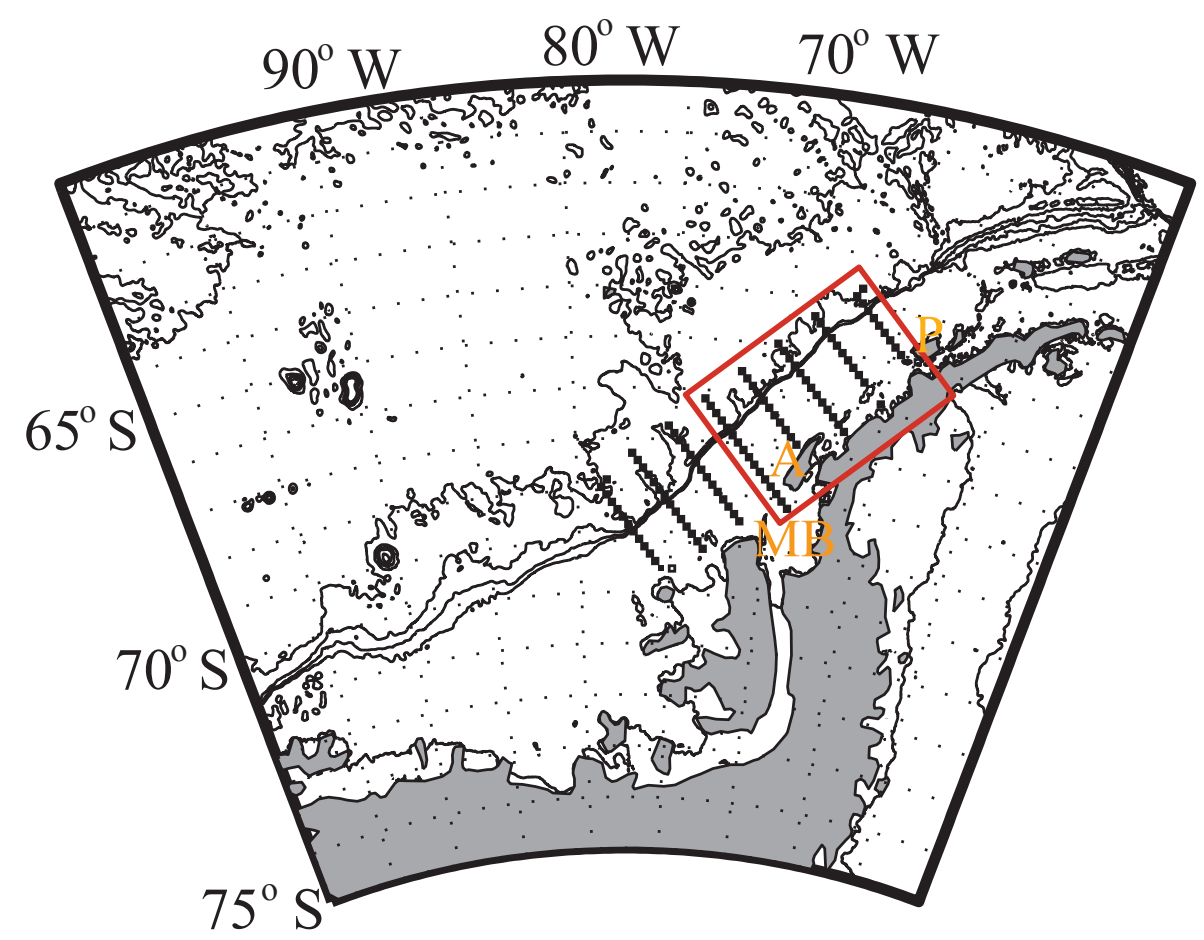

Figure 1. Map of the West Antarctic Peninsula (WAP) and study area of the Palmer Antarctica Long Term Ecological Research (PAL-LTER) project. The red box shows the main study grid that has been sampled for inorganic carbon chemistry since 1993, and is defined in this study as the central subregion. The black squares indicate the stations (20 km apart) arranged in onshore to offshore lines spaced $100 \mathrm{~km}$ apart along the peninsula. The inorganic carbon measurements from stations south of the central subregion were only added in 2009 . The central subregion also contains surface underway $p \mathrm{CO}_{2}$ observations that were used in the trend analysis (Sect. 3.5). P: Palmer Station on Anvers Island; A: Adelaide Island; and MB: Marguerite Bay.

In the WAP, carbon biogeochemistry is controlled by an interplay of physical and biological mechanisms, which include photosynthesis, respiration, freshwater input, gas exchange, sea-ice cover, winds, and horizontal advection (Carrillo and Karl, 1999; Carrillo et al., 2004; Wang et al., 2009; Montes-Hugo et al., 2010). The physical oceanography of the region is strongly influenced by equatorward flow at the continental shelf/slope break associated with the eastward flowing Antarctic Circumpolar Current that abuts the continental slope along the WAP region. On the shelf, there are indications of one or more cyclonic circulation cells with poleward flow inshore (Hofmann et al., 1996; Dinniman and Klinck, 2004; Martinson et al., 2008). Water mass properties are strongly influenced by subsurface intrusions onto the continental shelf of warm, nutrient- and dissolved inorganic carbon (DIC)-rich Upper Circumpolar Deep Water (UCDW), which appears to be modulated by topographic depressions and canyons (Martinson et al., 2008; Dinniman et al., 2011; Martinson and McKee, 2012). In winter, respiration processes and the entrained deep $\mathrm{CO}_{2}$-rich water increase the DIC concentration in surface waters to supersaturated levels of $\mathrm{CO}_{2}$ with respect to the atmosphere (Carrillo et al., 2004; Wang et al., 2009; Tortell et al., 2014; Legge et al., 2015). From austral spring through summer, sea ice retreats from north to south and from offshore to inshore (Smith and Stammerjohn, 2001). If not counteracted by strong winds, freshwater from melting sea ice, glaciers, and snow (Meredith et al., 2013) stabilizes the water column in close proximity to the inshore and southward moving sea-ice edge. Stratification and presumably iron availability provide favorable conditions for phytoplankton blooms (Garibotti et al., 2003, 2005; Vernet et al., 2008), resulting in a strong drawdown of DIC and flux of $\mathrm{CO}_{2}$ from the atmosphere into the ocean (Carrillo et al., 2004; Montes-Hugo et al., 2009; Wang et al., 2009). Subsequent iron depletion results in a decreasing trend of chlorophyll $a(\mathrm{Chl} a)$ from onshore to offshore, with interannual differences in the gradient strength, depending on the onset of the sea-ice retreat (Garibotti, 2005; Garibotti et al., 2005), but possibly also the timing of sampling in relation to the timing of sea-ice retreat and phytoplankton blooms.

The inorganic carbon dynamics are further complicated by large-scale atmospheric patterns. The El Niño-Southern Oscillation (ENSO) and Southern Annular Mode (SAM) drive the WAP climate and oceanography on interannual to multidecadal timescales (Yuan and Martinson, 2001; Stammerjohn et al., 2008a). During La Niña years, storms become longer and more intense, temperatures increase, and seaice extent decreases in the WAP region as a result of a 
strong low-pressure system driven by the poleward displacement of the polar jet (Yuan, 2004). Positive SAM phases are also associated with positive temperature anomalies over the Antarctic Peninsula and decreased sea-ice extent (Kwok, 2002; Stammerjohn et al., 2008b). Furthermore, the SAM brings the Southern Hemisphere westerly winds closer to Antarctica, which amplifies the typical features of La Niña. During these periods, nutrient and $\mathrm{CO}_{2}$-rich Circumpolar Deep Water intrudes more frequently on to the shelf (Martinson et al., 2008), potentially increasing $\left[\mathrm{CO}_{2}\right]$ on the shelf. On the other hand, weaker and fewer storms and spatial and temporal extension of sea-ice coverage are observed in negative phases of SAM, with associated stronger stratification of the water column and enhanced biological productivity (Saba et al., 2014). These features are further intensified when a negative SAM coincides with El Niño (Stammerjohn et al., 2008b).

The WAP oceanography and ecosystem have been intensely observed as part of the PAL-LTER (Palmer Long Term Ecological Research) program (http://pal.lternet.edu/) over the past two decades (Ducklow et al., 2007, 2012). Since 1993, this multifaceted data set has also contained seawater inorganic carbon measurements taken each January along transects shown in Fig. 1. We complement the summertime inorganic carbon measurements from PAL-LTER with surface underway $p \mathrm{CO}_{2}$ measurements that cover all four seasons (Takahashi et al., 2015). Here, we describe the spatial, seasonal, and interannual variability in the inorganic carbon system over the past two decades with the intention to improve our understanding of the main physical and biological controls. Furthermore, such a uniquely long data set allows us to gain first insights into the impacts of ocean acidification on the region.

\section{Data and methods}

\subsection{In situ data and calculation of carbonate system variables}

We used discrete measurements of seawater DIC, total alkalinity (TA), and nutrients collected during ship-based cruises as part of the PAL-LTER program, along with temperature and salinity from CTD casts. The data were gathered along the PAL-LTER sampling grid (Fig. 1), which runs $500 \mathrm{~km}$ along the coast and $250 \mathrm{~km}$ across the shelf. The along-shelf transects were spaced every $100 \mathrm{~km}$, with $20 \mathrm{~km}$ between the stations. The data were collected on an annual summertime cruise each January-February from 1993 through 2012. Carbon system sample collection and analysis were performed by David Karl and Chris Carrillo for data prior to 2003, and by Hugh Ducklow and Matthew Erickson for data from 2003 onward, with the exception that DIC analysis was done by Taro Takahashi in 2003 and 2004. No TA data were collected during 2003-2004.
Following the WOCE-JGOFS protocols, discrete samples of DIC and TA $(300 \mathrm{~mL})$ from Niskin bottle casts were preserved with $200 \mu \mathrm{L}$ of saturated $\mathrm{HgCl}_{2}$ solution and sealed (Dickson and Goyet, 1994). DIC was analyzed by coulometric determination of extracted $\mathrm{CO}_{2}$ (Johnson et al., 1987). TA was measured with the potentiometric titration method. Certified reference materials (provided by A. G. Dickson, Scripps Institution of Oceanography) were used to assure internal consistency of data with a precision of $\pm 2 \mu \mathrm{mol} \mathrm{kg}{ }^{-1}$ for DIC and $\pm 5 \mu \mathrm{mol} \mathrm{kg}^{-1}$ for TA. Water for inorganic nutrient analysis was subsampled from Niskin bottles into acidwashed $50 \mathrm{~mL}$ Falcon tubes and frozen at $-70^{\circ} \mathrm{C}$. The samples were first analyzed using a Lachat Quickchem 8000 autoanalyzer at the University of California at Santa Barbara Marine Science Institute Analytical Lab (1993-2007) and later at the Marine Biological Laboratory (Woods Hole MA, 2008-2012). Inorganic nutrient data reach a precision of $\pm 1 \%$. All PAL-LTER data and a detailed description of the sampling methodology are publicly available at http: //pal.lternet.edu/ (dissolved inorganic nutrients, PAL-LTER data set 27).

Calculated $\mathrm{pH}$ and saturation state for aragonite $\left(\Omega_{\text {arag }}\right)$ were determined from DIC, TA, temperature, salinity, phosphate, silicate, and pressure using the CO2SYS MATLAB version (van Heuven et al., 2011). To determine the carbonate variables we applied the dissociation constants for carbonic acid by Dickson and Millero (1987; refit from Mehrbach et al., 1973). The $\mathrm{CO}_{2}$ solubility equations of Weiss (1974) and dissociation constants for boric acid by Dickson (1990) were also used to determine $\mathrm{pH}$ and $\Omega_{\mathrm{arag}} \mathrm{pH}$ is reported on the total $\mathrm{H}^{+}$ion concentration scale $(\mathrm{pHT})$.

The Lamont-Doherty Earth Observatory (LDEO) measured surface underway $p \mathrm{CO}_{2}$ with a precision of $\pm 0.5 \%$, together with salinity and temperature in various seasons between 1999 and 2013, using a shower-type water-gas equilibrator and infrared $\mathrm{CO}_{2}$ gas analyzer (see www.ldeo. columbia.edu/pi/CO2 for the operational and engineering details; Takahashi et al., 2015). A range of five standard gas mixtures spanning between 100 and $700 \mathrm{ppm}$ mole fraction $\mathrm{CO}_{2}$ certified by the Earth System Research Laboratory of the National Oceanic and Atmospheric Administration (NOAA) was used to calibrate the system every $4 \mathrm{~h}$.

\subsection{Comparison with deep-water WOCE/CLIVAR inorganic carbon system data}

We checked the consistency of the PAL-LTER DIC and TA data by comparing PAL-LTER deep-water $(>2000 \mathrm{~m})$, offshore TA, and DIC measurements to deep-water data collected during the World Ocean Circulation Experiment (WOCE) and Climate and Ocean - Variability, Predictability, and Change (CLIVAR) cruises along parts of sections A21 and S4P that were overlapping with the PAL-LTER grid (data available at http://www.nodc.noaa.gov/woce/wdiu/). The WOCE and CLIVAR shipboard measurements were cal- 


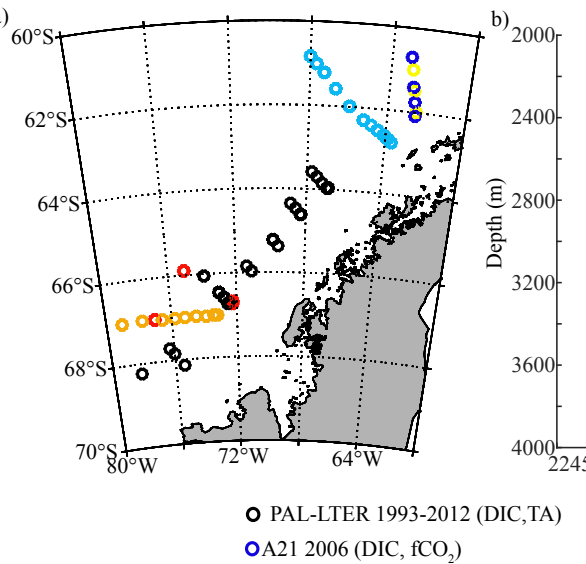

000000000

- 08.

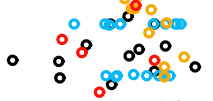

- o 000

- 00900

- 0000000

- 0 \%

$\circ 0^{\circ} \circ$

2255

oS4P 1992 (DIC, pCO

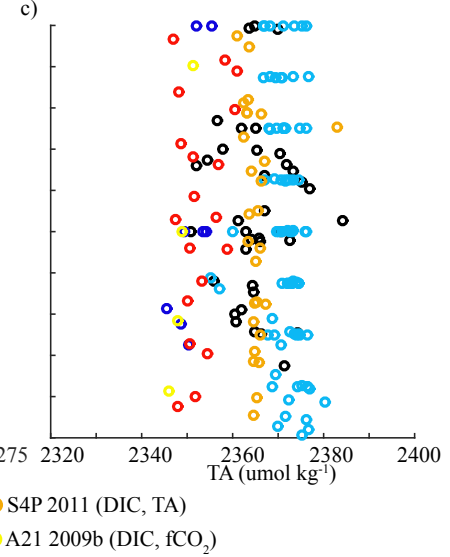

A21 2009b (DIC, fCO

Figure 2. Comparison of deep-water (off-shelf) dissolved inorganic carbon (DIC, $\mu \mathrm{mol} \mathrm{kg}{ }^{-1}$ ) and total alkalinity (TA, $\mu \mathrm{mol} \mathrm{kg}{ }^{-1}$ ) data from Palmer Station Long Term Ecological Research (PAL-LTER) with other available cruise data. (a) Station locations and (b) DIC and (c) TA depth profiles from PAL-LTER cruises (1998-2012), World Ocean Circulation Experiment (WOCE) and Climate and Ocean Variability, Predictability, and Change (CLIVAR) cruises along parts of sections A21 (2006, 2009) and S4P (1992, 2011). The directly measured parameters are listed in the parentheses and were used to calculate TA if not directly measured.

ibrated using seawater certified reference materials (prepared by A. G. Dickson, Scripps Institute of Oceanography), leading to an estimated precision of $\pm 2 \mu \mathrm{mol} \mathrm{kg}^{-1}$. DIC was measured on all cruises. When necessary, TA was calculated from DIC and either $f \mathrm{CO}_{2}$ or $p \mathrm{CO}_{2}$ following the same procedure as described in Sect. 2.1. Figure 2a shows the stations along the WAP where deep-water samples were taken during PAL-LTER and WOCE cruises. PAL-LTER DIC and TA measurements were within the range of sam$\mathrm{pled} / \mathrm{calculated}$ DIC and TA from the WOCE and CLIVAR cruises (Fig. $2 b$ and c). After removing five outliers, mean deep-water DIC $\left(\right.$ DIC ${ }^{\text {mean }}=2260.6 \pm 3.8 \mu \mathrm{mol} \mathrm{kg}^{-1}$ ) and $\mathrm{TA}\left(\mathrm{TA}^{\text {mean }}=2365.4 \pm 7.0 \mu \mathrm{mol} \mathrm{kg}{ }^{-1}\right)$ from PAL-LTER cruises corresponded well with the data measured/calculated from WOCE cruises $\left(\right.$ DIC ${ }^{\text {mean }}=2261.8 \pm 3.0 \mu \mathrm{mol} \mathrm{kg}^{-1}$; $\left.\mathrm{TA}^{\text {mean }}=2365.9 \pm 9.3 \mu \mathrm{mol} \mathrm{kg}^{-1}\right)$.

\subsection{Comparison with surface underway $\mathrm{pCO}_{2}$ data}

We also undertook a quality check of the PAL-LTER discrete surface DIC and TA data (depth $<5 \mathrm{~m}$ ) by comparing PAL-LTER $p \mathrm{CO}_{2}$, which was calculated using observed DIC and TA values, to LDEO $p \mathrm{CO}_{2}$. LDEO $p \mathrm{CO}_{2}$ samples that were collected during the PAL-LTER cruises were spatially matched with the PAL-LTER-derived $p \mathrm{CO}_{2}$ values by choosing the nearest latitude and longitude pair within a $1 \mathrm{~km}$ distance. Four PAL-LTER $p \mathrm{CO}_{2}$ outliers that underestimate/overestimate $p \mathrm{CO}_{2}$ relative to the underway observations by more than $150 \mu \mathrm{atm}$ were removed. Analysis of the corrected data set with a linear regression type II model suggests a correlation of $r=0.82$ (Fig. A1 in the Appendix, Table 1). Some of the observed discrepancies may be attributed to errors in matching the times of bottle samples with those of underway $p \mathrm{CO}_{2}$ measurements. Seawater inorganic carbon chemistry is highly variable along the WAP due to the influence of productivity, respiration, freshwater and upwelling of $\mathrm{CO}_{2}$-rich subsurface water (Carrillo et al., 2004). Small matching errors may therefore introduce small DIC and TA offsets, which would translate into larger fractional differences in $p \mathrm{CO}_{2}$ due to the large Revelle factor $\left(\partial \ln p \mathrm{CO}_{2} / \partial\right.$ ln DIC) common in the region (Sarmiento and Gruber, 2006).

\section{Results}

Here, we examine the observed spatial summer patterns of DIC, TA, pHT, and $\Omega_{\text {arag }}$ along the WAP and explore the underlying biological and physical drivers. We then discuss regional carbon-nutrient drawdown ratios and present our seasonal $\Omega_{\text {arag }}$ predictions that give initial insights into the chemical environment in the more poorly sampled spring, fall, and winter months. Finally, using the LTER and LDEO data sets, we investigate temporal trends over the past two decades.

\subsection{Spatial summertime patterns of the inorganic carbon system}

Surface waters in the PAL-LTER region exhibited high spatial and interannual variability in DIC $(\min =1850$ and $\left.\max =2173 \mu \mathrm{mol} \mathrm{kg}^{-1}\right), \quad$ TA $\quad(\min =2087 \quad$ and $\left.\max =2396 \mu \mathrm{mol} \mathrm{kg}^{-1}\right)$, and salinity $(\min =30.3$ and $\max =33.9$ ) across the shelf. As a result, surface $\Omega_{\text {arag }}$ reached levels as low as 0.98 in 1996, while maximum $\Omega_{\text {arag }}$ values were $>3$ in several years (Fig. 3). Offshore, DIC $(\min =2072$ and $\max =2255 \mu \mathrm{mol} \mathrm{kg}-1)$, TA (2265 and $\left.2355 \mu \mathrm{mol} \mathrm{kg}{ }^{-1}\right)$, and salinity $(\min =33.4$ and $\max =34)$ were less variable, resulting in a smaller $\Omega_{\text {arag }}$ range $(\min =1.14$ and $\max =2.41)$. Additional aragonite under- 
Table 1. Comparison of Lamont-Doherty Earth Observatory of Columbia University (LDEO) underway $p \mathrm{CO}_{2}$ ( $\mu$ atm) data (Takahashi et al., 2015) with the $p \mathrm{CO}_{2}$ ( $\left.\mu \mathrm{atm}\right)$ derived from PAL-LTER discrete surface samples over the Palmer-Long Term Ecological Research (PALLTER) sampling grid. The PAL-LTER discrete $p \mathrm{CO}_{2}$ sample values were computed using the dissolved inorganic carbon (DIC, $\mu$ mol kg ${ }^{-1}$ ) and total alkalinity (TA, $\mu \mathrm{mol} \mathrm{kg}{ }^{-1}$ ). The analysis is based on the data after removing outliers as explained in the text.

\begin{tabular}{llrrcrc}
\hline & & Mean (SD) & $r$ & Slope & Intercept & $n$ \\
\hline \multirow{2}{*}{2005} & LDEO & $293(79)$ & 0.94 & $1.05( \pm 0.06)$ & $-45.7( \pm 17.0)$ & 49 \\
& PAL-LTER & $322(75)$ & & & & \\
\hline \multirow{2}{*}{2006} & LDEO & $248(46)$ & 0.90 & $0.95( \pm 0.06)$ & $13.2( \pm 15)$ & 55 \\
& PAL-LTER & $248(48)$ & & & & \\
\hline \multirow{2}{*}{2007} & LDEO & $261(61)$ & 0.87 & $1.04( \pm 0.08)$ & $14.7( \pm 18.5)$ & 60 \\
& PAL-LTER & $237(59)$ & & & $158( \pm 42.5)$ & 48 \\
\hline \multirow{2}{*}{2008} & LDEO & $340(28)$ & 0.53 & $0.61( \pm 0.14)$ & & \\
& PAL-LTER & $299(37)$ & & & & \\
\hline \multirow{2}{*}{2009} & LDEO & $318(24)$ & 0.58 & $0.47( \pm 0.13)$ & & \\
& PAL-LTER & $292(37)$ & & & & \\
\hline \multirow{2}{*}{2010} & LDEO & $327(35)$ & 0.54 & $1.62( \pm 0.57)$ & $-167( \pm 174)$ & 20 \\
& PAL-LTER & $305(27)$ & & & & \\
\hline \multirow{2}{*}{2011} & LDEO & $226(98)$ & 0.93 & $0.97( \pm 0.9)$ & $0.60( \pm 21.4)$ & 21 \\
& PAL-LTER & $233(101)$ & & & & \\
\hline 2012 & LDEO & $354(36)$ & 0.46 & $1.44( \pm 0.63)$ & $-47.7( \pm 172)$ & 21 \\
& PAL-LTER & $279(30)$ & & & & \\
\hline \multirow{2}{*}{ All } & LDEO & $290(69)$ & 0.82 & $1.08( \pm 0.04)$ & $-5.57( \pm 12.2)$ & 300 \\
& PAL-LTER & $275(65)$ & & & & \\
\hline
\end{tabular}

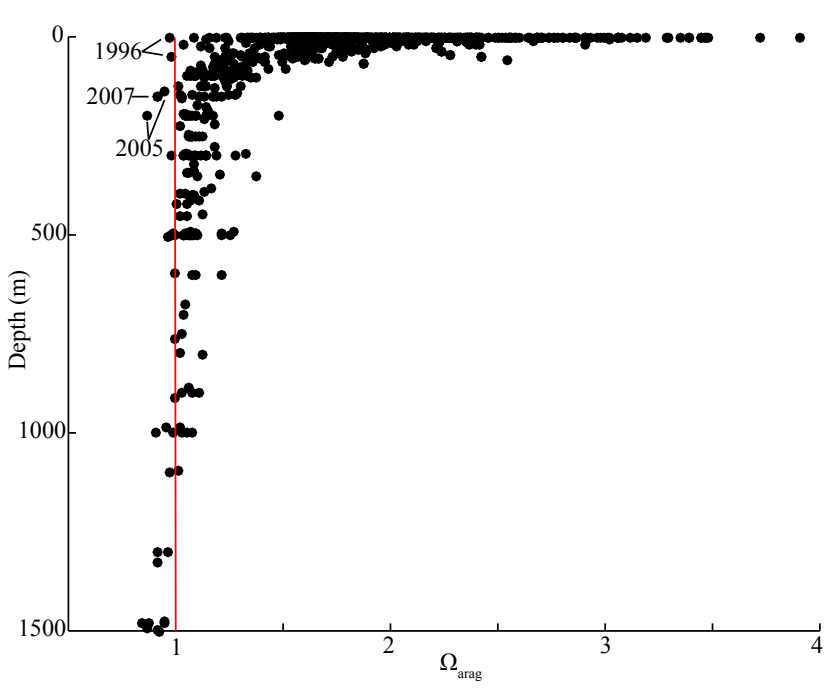

Figure 3. Depth profiles of aragonite saturation state $\left(\Omega_{\mathrm{arag}}\right)$ for the years 1993 through 2012. The aragonite saturation horizon for each year is located where the profile crosses the red line $\left(\Omega_{\text {arag }}=1.0\right)$.

saturation was detected between 100 and $200 \mathrm{~m}$ depth in 2005 and 2007 (Fig. 3). At depths $>70 \mathrm{~m}$, which is below the mixed layer depth, $\Omega_{\text {arag }}$ was $<1.5$ in all years.
To gain a spatial overview of the general summertime surface features (upper $5 \mathrm{~m}$ ), we linearly interpolated the observations in space and averaged across years with available DIC and TA (or nutrient) measurements. Averages are only shown for regions where samples were taken in more than 5 years (Fig. 4). The resulting $p \mathrm{CO}_{2}$, pHT, $\Omega_{\mathrm{arag}}$, TA, salinity, DIC, and nutrient fields exhibited clear onshoreoffshore gradients. With the exception of DIC, all variables also followed a north-south gradient. Mean summertime surface $p \mathrm{CO}_{2}$ was lowest $(<200 \mu \mathrm{atm})$ in the southern coastal region and was about 60 to $70 \mu$ atm lower than in the northern near-shore regions (Fig. 4a). The highest mean summertime $p \mathrm{CO}_{2}$ values were found in the northern slope region (300-325 $\mu \mathrm{atm})$. The opposite pattern was reflected in $\Omega_{\mathrm{arag}}$ and pHT, with highest values $\left(\Omega_{\text {arag }}^{\max }=2.6\right.$ and $\left.\mathrm{pHT}^{\max } 8.3\right)$ close to the coast and south of $66.5^{\circ} \mathrm{S}$ (Fig. $4 \mathrm{~b}$ and c), decreasing along the coast towards the north to $\mathrm{pHT} \sim 8.2$ and $\Omega_{\text {arag }} \sim 1.9$, and reaching the lowest levels in northern offshore waters $\left(\mathrm{pHT}^{\mathrm{min}}=8.1 ; \Omega_{\text {arag }}^{\min }=1.7\right)$. TA also exhibited north-south and onshore-offshore gradients, with values as low as $2185 \mu \mathrm{mol} \mathrm{kg}^{-1}$ in the northern near-shore regions and as high as $>2300 \mu \mathrm{mol} \mathrm{kg}{ }^{-1}$ offshore. The low TA values along the northern part of the coast coincided with the lowest salinity values of 31.8, suggesting dilution of TA due to freshwater input (Fig. 4d and e). Higher TA values 

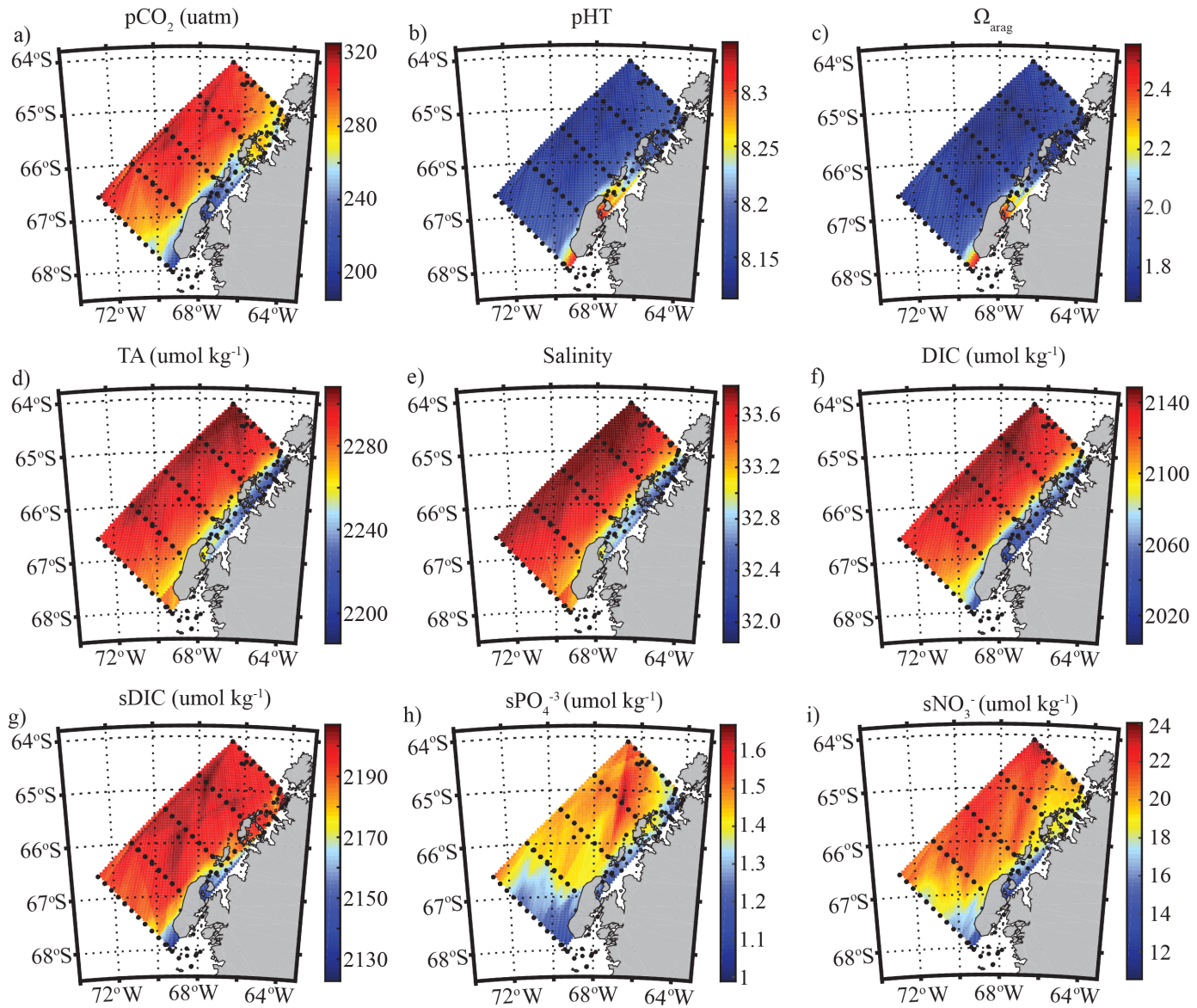

Figure 4. Maps of summertime averages of surface (a) $p \mathrm{CO}_{2}$, (b) pHT, (c) aragonite saturation state $\left(\Omega_{\text {arag }}\right)$, (d) total alkalinity (TA, $\mu \mathrm{mol} \mathrm{kg}{ }^{-1}$ ), (e) salinity, (f) dissolved inorganic carbon (DIC, $\mu \mathrm{mol} \mathrm{kg}-1$ ), and (g) salinity-normalized DIC (sDIC, $\mu \mathrm{mol} \mathrm{kg}{ }^{-1}$ ) across years with available DIC and TA measurements (1993-1999, 2001-2002, and 2005-2012). Salinity-normalized $\mathrm{PO}_{4}^{3-}\left(\mathrm{sPO}_{4}^{3-} \mu \mathrm{mol} \mathrm{kg}^{-1}\right)$ and salinity-normalized $\mathrm{NO}_{3}^{-}\left(\mathrm{sNO}_{3}^{-}, \mu \mathrm{mol} \mathrm{kg}{ }^{-1}\right)$ were averaged across 1993-1996, 1999, and 2001-2012. Averages are only shown for regions where samples were taken in five or more years. Occupied stations are shown by black dots.

offshore were also reflected in increased DIC and salinity concentrations, with temperatures between 1.3 and $1.5^{\circ} \mathrm{C}$. DIC also exhibited an onshore-offshore gradient with values about 80 to $100 \mu \mathrm{mol} \mathrm{kg}^{-1}$ lower in the near-shore region compared to offshore, but there was no significant northsouth gradient despite the presence of freshwater in the north (Fig. 4f). Salinity-normalized DIC (sDIC, normalized with UCDW salinity $=34.7$ ) was lowest in the southern region, thereby indicating that biological processes likely counteracted the expected north-south DIC gradient due to the pronounced freshwater influence on DIC in the north (Fig. 4g).

\subsection{Physical and biological drivers of the inorganic carbon system}

In this section we examine the physical and biological mechanisms that control the observed variability in DIC and TA. DIC can decrease (increase) through dilution with freshwater (evaporation), organic matter production (remineralization),
$\mathrm{CO}_{2}$ outgassing to the atmosphere $\left(\mathrm{CO}_{2}\right.$ uptake), and/or precipitation of $\mathrm{CaCO}_{3}$ (dissolution). While positive net community production decreases DIC, the biological effect of organic matter production on TA depends on the source of nitrogen, where nitrate consumption increases TA and ammonium consumption decreases TA (Goldman and Brewer, 1980). Since nitrate is more abundant than ammonium in WAP surface waters (Serebrennikova and Fanning, 2004), nitrate was assumed as the nitrogen source. With a Redfield stoichiometry of $6.6 \mathrm{~mol} \mathrm{Cmol} \mathrm{N}^{-1}$, TA should increase by $1 / 6.6=+0.15 \mu \mathrm{mol}$ TA per $\mu \mathrm{mol}$ DIC consumed. Precipitation of biological $\mathrm{CaCO}_{3}$ material reduces both DIC and TA, with the effect on TA twice as large as that on DIC $\left(2 \mu \mathrm{mol} \mu \mathrm{mol}^{-1}\right)$. TA is not affected by gas exchange but does vary as a result of dilution and evaporation.

Indications of surface reductions in TA and DIC due to freshwater input are evident along the WAP, and therefore freshwater processes (sea-ice and glacial melt, precipitation; Meredith et al., 2013) appear to be important factors influ- 


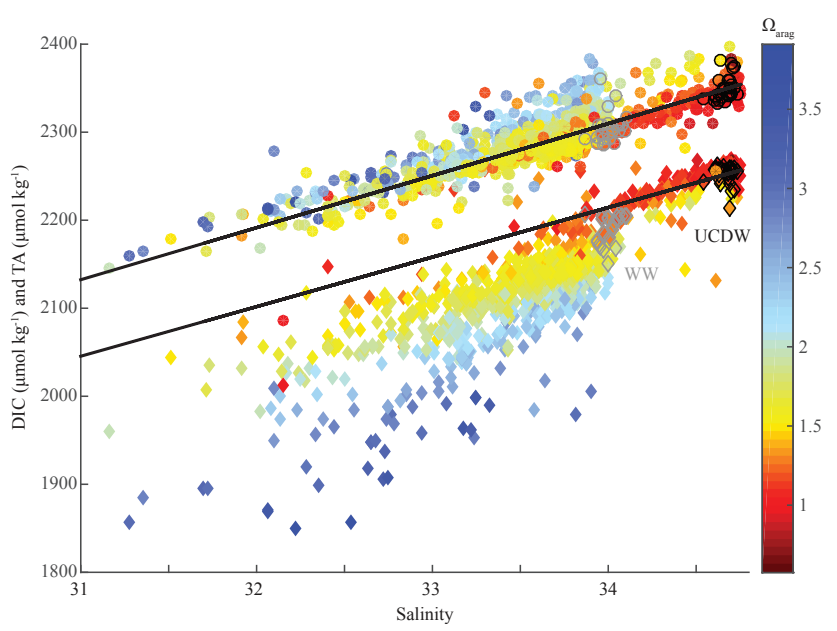

Figure 5. Scatterplots of dissolved inorganic carbon (DIC, $\mu \mathrm{mol} \mathrm{kg} \mathrm{kg}^{-1}$ ) illustrated as diamonds and total alkalinity (TA, $\mu \mathrm{mol} \mathrm{kg}-1$ ) illustrated as dots as a function of salinity. The data points are color-coded by the aragonite saturation state $\left(\Omega_{\text {arag }}\right)$. The solid lines illustrate the dilution lines using $S=34.7, \quad \mathrm{TA}=2350 \mu \mathrm{mol} \mathrm{kg}-1, \quad$ and $\quad \mathrm{DIC}=2253 \mu \mathrm{mol} \mathrm{kg}-1$ as end members for UCDW, and $S=0, \mathrm{TA}=300 \mu \mathrm{mol} \mathrm{kg}-1$, and $\mathrm{DIC}=300 \mu \mathrm{mol} \mathrm{kg}-1$ as end members for meltwater (Yamamoto-Kawai et al., 2009). WW: winter water $\left(T \leq-1.2{ }^{\circ} \mathrm{C}\right.$; $33.85 \leq S \leq 34.13)$; UCDW: Upper Circumpolar Deep Water $\left(1.7^{\circ} \mathrm{C} \geq T \leq 2.13^{\circ} \mathrm{C} ; 34.54 \leq S \leq 34.75\right)$ following (Martinson et al., 2008).

encing the summertime carbon dynamics along the WAP. Figure 5 shows TA (circles) and DIC (diamonds) as a function of salinity. The black lines represent the dilution lines for TA and DIC, which were calculated following YamamotoKawai et al. (2009). UCDW end members are based on average TA and DIC concentrations in the water mass identified as UCDW (black frames; Martinson et al., 2008). Upperocean TA follows its dilution line closely, with stronger positive deviations of about $35 \mu \mathrm{mol} \mathrm{kg}-1$ on average. In contrast, DIC values fall considerably below the dilution line. A DIC drawdown of about $60 \mu \mathrm{mol} \mathrm{kg}-1$ is visible in the winter water (grey diamonds), which increased to more than $200 \mu \mathrm{mol} \mathrm{kg}^{-1}$ in the mixed layer, leading to $\Omega_{\text {arag }}$ as low as 1.5 and as high as 3.9.

The DIC drawdown relative to the salinity mixingdilution line is most likely due to biological production of organic matter. Figure 6 shows sDIC as a function of salinity-normalized TA (sTA) for waters shallower than UCDW (orange dots). The regression line (solid black line, $\mathrm{sTA}=-0.11 \times \mathrm{sDIC}+2601, \mathrm{RMSE}=18.6) \pm 2 \sigma$ (dashed lines) for estimated measurement precision $(\sigma=$ $\left.\pm 5 \mu \mathrm{mol} \mathrm{kg}{ }^{-1}\right)$ is similar to the nitrate-based photosynthesis line (blue line), indicating that the large decrease in DIC with the concomitant smaller increase in TA was mainly due to net biological production of organic matter. The photosynthesis line is based on winter water (WW) DIC and TA end

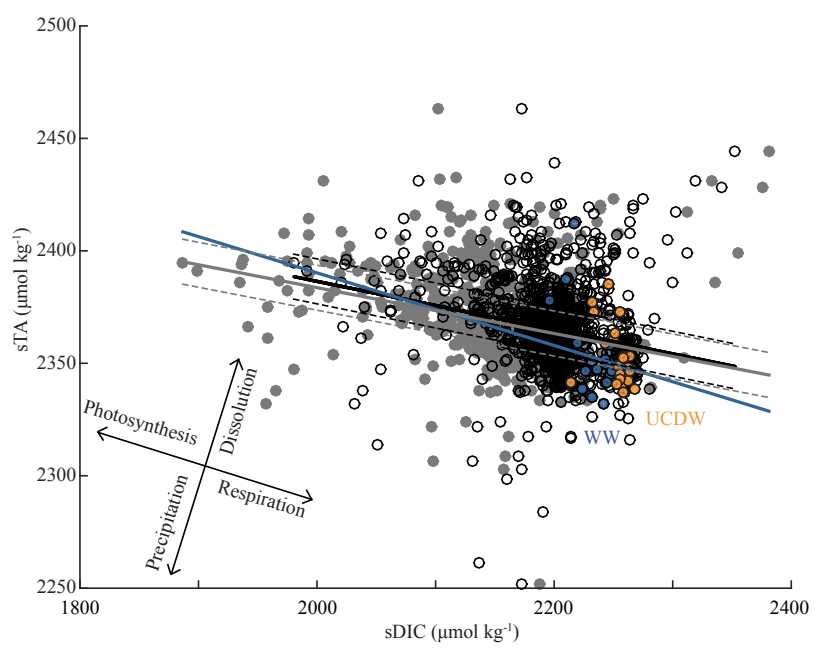

Figure 6. Salinity-normalized total alkalinity (sTA, $\mu \mathrm{mol} \mathrm{kg}-1$ ) as a function of salinity-normalized dissolved inorganic carbon (sDIC, $\mu \mathrm{mol} \mathrm{kg}{ }^{-1}$ ) for waters shallower than the Upper Circumpolar Deep Water (UCDW, orange circles). A linear fit between sTA and sDIC is shown by the black solid line. The dotted black lines indicate $2 \sigma$ for estimated measurement precision of $\sigma= \pm 5 \mu \mathrm{mol} \mathrm{kg}-1$. The blue line illustrates the trend if STA and sDIC of the winter water (WW) were only influenced by photosynthesis $(1:-6.2)$. Grey dots represent sTA as a function of sDIC corrected for gas exchange in the waters above the WW, and the linear fits with the estimated measurement precision are the grey solid and dashed lines respectively. WW: $T \leq-1.2^{\circ} \mathrm{C}, 33.85 \leq S \leq 34.13$; UCDW: $1.7^{\circ} \mathrm{C} \geq T \leq 2.13^{\circ} \mathrm{C}, 34.54 \leq S \leq 34.75$, following (Martinson et al., 2008).

members (blue dots) and a slope of $-1 / 6.2$. According to the Redfield ratios (C / N / P = 106 : 16 : 1; Redfield, 1958), photosynthetic utilization of $1 \mathrm{~mol}$ of $\mathrm{NO}_{3}$ increases TA by $1 \mu \mathrm{mol} \mathrm{kg}{ }^{-1}$ (Wolf-Gladrow et al., 2007) and decreases DIC by $106 / 16$ (6.6). However, since the TA titration was performed to a pHT of about 3 , the TA values include residual $\mathrm{PO}_{4}^{-3}$, which leads to this slightly shallower slope of 6.2 .

The intense, biologically driven DIC drawdown and resulting $p \mathrm{CO}_{2}$ undersaturation in the mixed layer may have led to some $\mathrm{CO}_{2}$ uptake from the atmosphere that tends to reduce the apparent DIC deficit; thus the estimated biological drawdown from observed DIC values in Fig. 6 may be underestimated and needs to be corrected for air-sea $\mathrm{CO}_{2}$ gas exchange from the period of biological drawdown to the sampling time. To account for DIC concentration changes due to gas exchange with the atmosphere, we assumed a constant atmospheric concentration of $390 \mu$ atm between 1993 and 2012, and a gas transfer rate $(k)$ of $5( \pm 1) \mathrm{mmol}$ $\mathrm{CO}_{2} \mathrm{~m}^{-2} \mu \mathrm{atm}^{-1}$ month $^{-1}$, which is the estimated mean rate for the Southern Ocean area south of $62^{\circ} \mathrm{S}$ (Takahashi et al., 2009). The change in DIC ( $\mu \mathrm{mol} \mathrm{kg}{ }^{-1}$ month $^{-1}$ ) due to gas transfer into the mixed layer (ML) of $d$ meters depth is

$\Delta \mathrm{DIC}=k \times \Delta t \times \Delta p \mathrm{CO}_{2} / d$. 
$\Delta p \mathrm{CO}_{2} \quad\left(p \mathrm{CO}_{2}^{\mathrm{atm}}-p \mathrm{CO}_{2}^{\mathrm{ML}}\right)$ was between -143 and $312 \mu$ atm, as $p \mathrm{CO}_{2}^{\mathrm{ML}}$ ranged from 533 to $78 \mu$ atm, indicating that there was potential for both oceanic $\mathrm{CO}_{2}$ uptake and outgassing. Assuming that $d=50 \mathrm{~m}$ (Ducklow et al., 2013), we estimate that the monthly $\triangle \mathrm{DIC}$ due to air-sea $\mathrm{CO}_{2}$ gas exchange was in the range of -14 to $31 \mu \mathrm{mol} \mathrm{kg}^{-1}$ month $^{-1}$. Since the first large phytoplankton blooms generally occur after the sea ice retreats in November $(\Delta t \sim 3$ months), we assume that by the time of sampling at the end of January, $\triangle$ DIC would fall in the range -43 to $94 \mu \mathrm{mol} \mathrm{kg}{ }^{-1}$. The DIC corrected for gas exchange is illustrated as grey dots in Fig. 6. While applying the gas exchange correction flattens the regression line (grey line) somewhat, the photosynthesis line (blue) still remains within the estimated error bounds of the gas-exchange-corrected regression line (grey dotted lines), further emphasizing that photosynthesis is the key biological driver of the summertime carbonate system west of the Antarctic Peninsula.

\subsection{Nutrient vs. carbon drawdown}

Ocean carbon, nitrogen and phosphorus cycles are governed by organic matter production and subsequent remineralization and are strongly correlated on a global average with the proportions $\mathrm{C} / \mathrm{N} / \mathrm{P}=106: 16: 1$ (Redfield, 1958). Our findings suggest that the carbon-nutrient cycles along the WAP depart from the standard Redfield values (Fig. 7). In a few samples, the standing stock of $\mathrm{PO}_{4}^{3-}$ became depleted before $\mathrm{NO}_{3}^{-}$, and overall the regression indicates a low $\mathrm{N}: \mathrm{P}$ ratio of $9.8 \pm 0.4$ in the mixed layer (Fig. 7a, black) and $\mathrm{N}: \mathrm{P}=11.7 \pm 0.3$ for all data (dark grey) relative to the standard Redfield value of $16 \mathrm{~mol} \mathrm{~N} \mathrm{~mol} \mathrm{P}^{-1}$. The mole/mole $\mathrm{C}: \mathrm{P}$ ratio was also considerably smaller than the Redfield ratio (Fig. 7b). C:P yielded $43.1 \pm 2.3$ in the mixed layer and $55.0 \pm 1.7$ for all data. However, after applying the gas exchange correction on DIC (see Sect. 2), the C:P ratio shifted closer to the Redfield ratio and resulted in a value of $80.5 \pm 2.5$ (light-grey dots and lines). Correcting the DIC for gas exchange shifted the $\mathrm{C}: \mathrm{N}$ molar ratio from $4.5 \pm 0.2$ (mixed layer depth) and $4.7 \pm 0.1$ (all data) to $6.7 \pm 0.2$ and resulted in a Redfield-like $\mathrm{C}: \mathrm{N}$ ratio.

\subsection{Seasonal variability}

To get insights into the carbon dynamics during winter, spring, and fall, when direct measurements of DIC, TA, and nutrients are either scarce or not available, we developed a regional TA algorithm (based on PAL-LTER summertime data). In combination with seasonal LDEO $p \mathrm{CO}_{2}$, salinity, and temperature data, we calculated $\Omega_{\text {arag }}$ for the missing seasons. Due to the weak correlation between PAL-LTER temperature and TA $(r=0.50)$, we based the TA algorithm on salinity only (Fig. A2, $r=0.88$ ). Applying the Akaike information criterion (Burnham and Anderson, 2002), we determined that TA along the WAP will be best represented by a
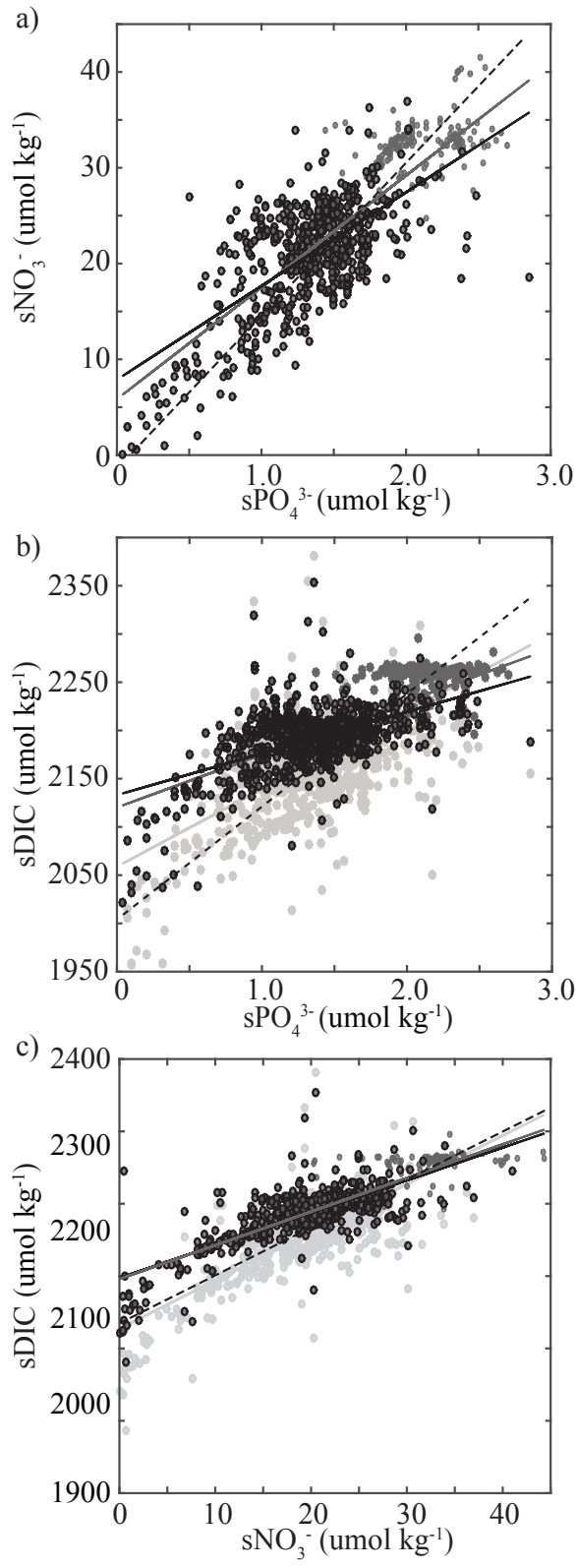

Figure 7. Plot of salinity-normalized nutrients and dissolved inorganic carbon (sDIC, $\left.\mu \mathrm{mol} \mathrm{kg}{ }^{-1}\right),\left(\right.$ a) $\mathrm{sPO}_{4}^{3-}\left(\mu \mathrm{mol} \mathrm{kg}{ }^{-1}\right.$ ) vs. $\mathrm{sNO}_{3}^{-}$ $\left(\mu \mathrm{mol} \mathrm{kg}{ }^{-1}\right)$, (b) $\mathrm{sPO}_{4}^{3-}$ vs. sDIC, and (c) $\mathrm{sNO}_{3}^{-}$vs. sDIC. Observations within the mixed layer (depth $<50 \mathrm{~m}$ ) are illustrated by black circles. The light-grey dots in (b) and (c) show sDIC corrected for gas exchange as a function of $\mathrm{sPO}_{4}^{3-}$ and $\mathrm{sNO}_{3}^{-}$, respectively. A linear fit is represented by the solid black line for the mixed layer, by the solid grey line for all data, and by the light-grey line for the gas-exchange-corrected sDIC in (b) and (c). The dashed black lines are the nutrient drawdown lines using the corresponding Redfield ratio and data from the Upper Circumpolar Deep Water (UCDW) as end members.

first-order linear model. We then randomly divided the PALLTER surface measurements (depth $<5 \mathrm{~m}$ ) into 10 data sub- 
sets using the 10-fold cross-validation method (Stone, 1974; Breiman, 1996). Using 9 of the 10 data sets we derived a regression model, predicted the TA with the model, and calculated the model coefficients and root mean square errors (RMSEs). We repeated these steps so that every data subset was left out once. The coefficients for the final model were calculated from the mean of the ten regression coefficients. We found the best fit to predict TA ( $\mathrm{TA}^{\text {pred }}, \mu \mathrm{mol} \mathrm{kg}{ }^{-1}$ ) in the following equation:

$\mathrm{TA}^{\text {pred }}=57.01( \pm 0.88) \times S+373.86( \pm 35.26)$,

which resulted in a linear correlation coefficient of $r=0.88$ and a RMSE of $15.2 \mu \mathrm{mol} \mathrm{kg}{ }^{-1}$ (Fig. A2). In combination with the $p \mathrm{CO}_{2}$ measurement precision of $3 \mu \mathrm{atm}$, the RMSE of TA prediction resulted in a mean error in calculated $\Omega_{\mathrm{arag}}$ of 0.0219 units and pHT of 0.0043 (Glover et al., 2011). Note that the calculated $\Omega_{\text {arag }}$ and pHT estimates implicitly require that the approximately linear summertime TA-salinity relationship hold for the other seasons, a reasonable assumption if dilution and mixing substantially affect TA patterns.

Summertime LDEO underway $p \mathrm{CO}_{2}$ values were, on average, lower than during the rest of the year (Fig. 8a). While only a small percentage of these summertime values reached levels higher than the atmospheric $\mathrm{CO}_{2}$ concentration, $70 \%$ of the water samples taken in winter were supersaturated with regard to atmospheric $\mathrm{CO}_{2}(>390 \mu \mathrm{atm})$. Spring and fall $p \mathrm{CO}_{2}$ values were also generally higher than summertime measurements and ranged from 207 to $506 \mu$ atm and 90 to $414 \mu \mathrm{atm}$.

Our salinity-based algorithm predicted the majority of all TA ranging between 2200 and $2300 \mu \mathrm{mol} \mathrm{kg}{ }^{-1}$ in all seasons, with the most frequent occurrence of highest TA in winter and spring (Fig. 8b). Some summertime TA was predicted to be as low as $2056 \mu \mathrm{mol} \mathrm{kg}{ }^{-1}$.

Prediction of seasonal $\Omega_{\text {arag }}$ revealed that surface waters of the WAP were supersaturated with regard to aragonite throughout the years (Fig. 8c). The most frequent occurrence of low $\Omega_{\text {arag }}$ was in winter and spring, when most of the predicted values resulted in $\Omega_{\mathrm{arag}}<1.4 .20 \%$ of spring and winter values were $\Omega_{\mathrm{arag}}<1.2$, with the lowest predicted surface $\Omega_{\text {arag }}$ reaching near aragonite undersaturation in winter. Similar to the LTER observations, predicted summertime $\Omega_{\text {arag }}$ displayed a large range, spanning from 1.1 to 4.1 , with the majority of predictions between 1.3 and 1.8. Biological production in summer is sufficiently intense to prevent low $\Omega_{\text {arag }}$ values during the active growing season, when its effects might be most pronounced.

\subsection{Temporal trends}

Trend analysis of the PAL-LTER data showed no statistically significant annual trends (at the $95 \%$ confidence level) in the measured carbon parameters, temperature, or salinity in surface waters in summer between 1993 and 2012 (Table 2). As a comparison, we conducted a trend analysis for the LDEO
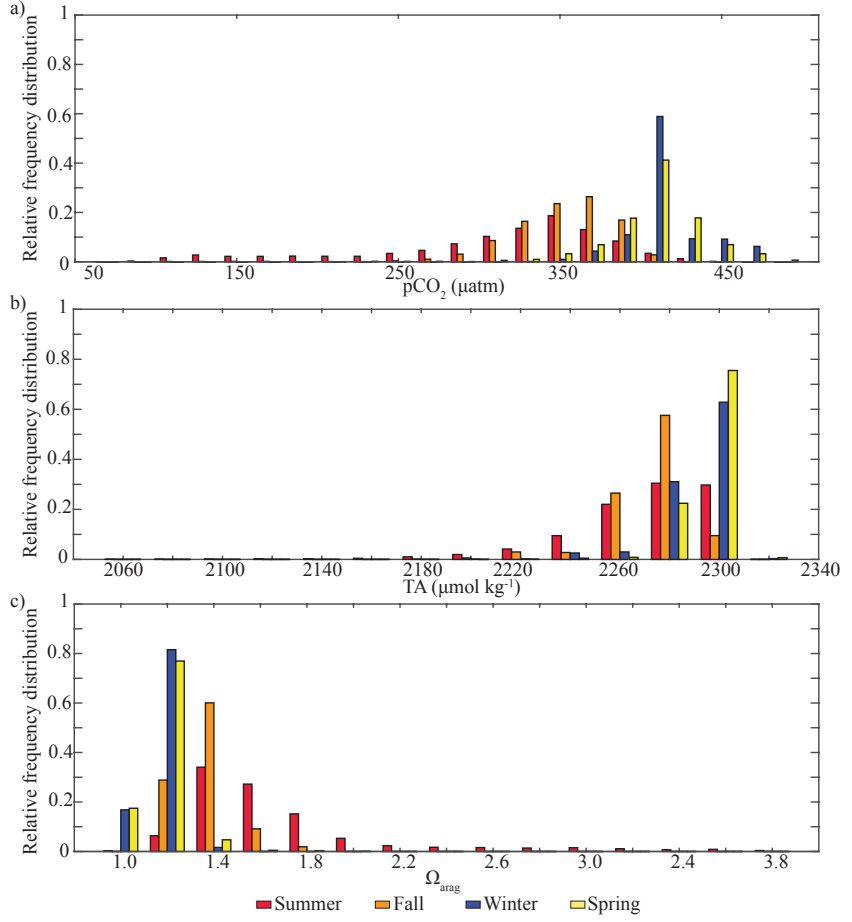

Figure 8. Seasonal variability in the inorganic carbon system. Relative frequency distribution of (a) measured underway surface partial pressure $p \mathrm{CO}_{2}(\mu \mathrm{atm})$, (b) predicted surface total alkalinity $\left(\mathrm{TA}, \mu \mathrm{mol} \mathrm{kg}{ }^{-1}\right.$ ) from underway salinity, and (c) predicted surface aragonite saturation state $\left(\Omega_{\mathrm{arag}}\right)$ in summer (red), fall (orange), winter (blue), and spring (yellow). The $x$ axis represents the range of $\Omega_{\text {arag }}$, TA, and $p \mathrm{CO}_{2}$ with a relative frequency distribution $\geq 0.0001$.

surface underway $p \mathrm{CO}_{2}$ data set (1999-2013) in the same region. LDEO observations show an increasing, but not statistically significant, trend in surface $p \mathrm{CO}_{2}$, supporting our results above (Table 3 ). The largest increasing trend was found in fall $\left(1.9 \pm 0.95 \mu \mathrm{atm} \mathrm{yr}^{-1}\right)$, but this trend was also slightly outside the confidence interval and therefore statistically not significant.

\section{Discussion}

The 20-year-long PAL-LTER seawater inorganic carbon time series showed a distinct upper-ocean spatial pattern of onshore-offshore and north-south gradients and suggests that the summertime carbon dynamics are primarily controlled by biological productivity and freshwater input in near-shore areas.

Surface $\Omega_{\text {arag }}$ was distributed across a wide range $(<1$ to values $>3$ ) in freshwater-influenced areas with salinities $S<32$ (Fig. 5). To better understand how such a wide range of $\Omega_{\text {arag }}$ at relatively low salinities was possible, we quantified the effect of freshwater and biological production. Mixing of seawater with sea-ice or glacial meltwater leads to a 
Table 2. Mean annual trend (1993-2012) of Palmer-Long Term Ecological Research (PAL-LTER) surface (depth $<5$ m) carbonate chemistry and hydrography from the West Antarctic Peninsula (central subregion). Regression statistics include the mean annual rate (yr ${ }^{-1}$ ), standard error (SE), number of measurements $(\mathrm{NM})$, number of years $(\mathrm{NY}), r$-squared, and $p$ value for aragonite saturation state $\left(\Omega_{\text {arag }}\right)$, pHT, dissolved inorganic carbon (DIC, $\mu \mathrm{mol} \mathrm{kg}{ }^{-1}$ ), total alkalinity (TA, $\mu \mathrm{mol} \mathrm{kg}{ }^{-1}$ ), temperature $\left({ }^{\circ} \mathrm{C}\right.$ ), and salinity. Trends with a $p$ value $<0.05$ would be considered statistically significant at the $95 \%$ confidence level. Points that were outliers at $95 \%$ probability level were excluded (o).

\begin{tabular}{lrrrrr}
\hline Parameter & Rate $\left(\mathrm{yr}^{-1}\right) \pm \mathrm{SE}$ & $\mathrm{NM}(\mathrm{o})$ & $\mathrm{NY}$ & $r^{2}$ & $p$ value \\
\hline \multicolumn{5}{c}{ Surface $(<5 \mathrm{~m}$ depth $)$} \\
$\Omega_{\text {arag }}$ & $0.001 \pm 0.01$ & $892(17)$ & 18 & 0.04 & 0.9127 \\
$\mathrm{pHT}$ & $0.002 \pm 0.002$ & $892(8)$ & 18 & 0.03 & 0.2784 \\
DIC $\left(\mu \mathrm{mol} \mathrm{kg}^{-1}\right)$ & $-0.18 \pm 1.03$ & $907(0)$ & 18 & 0.00 & 0.8677 \\
TA $\left(\mu \mathrm{mol} \mathrm{kg}^{-1}\right)$ & $0.58 \pm 0.63$ & $907(0)$ & 18 & 0.05 & 0.3681 \\
Temperature $\left({ }^{\circ} \mathrm{C}\right)$ & $-0.01 \pm 0.02$ & $1076(8)$ & 20 & 0.01 & 0.4629 \\
Salinity & $0.01 \pm 0.01$ & $1060(8)$ & 20 & 0.12 & 0.1349 \\
\hline
\end{tabular}

"dilution" of $\mathrm{CO}_{3}^{2-}$ ions and a decrease in $\Omega_{\text {arag }}$ because TA and DIC in glacial and sea-ice meltwater are much lower than in seawater (Anderson et al., 2000; Yamamoto-Kawai et al., 2009). Calculations of salinity-normalized $\Omega_{\text {arag }}$ using sDIC and sTA showed that freshwater input decreased $\Omega_{\text {arag }}$ by up to 0.2 units along the coast. Despite the negative effect of freshwater on $\Omega_{\text {arag }}$, the water in the south was nonetheless highly supersaturated with $\mathrm{CaCO}_{3}$. The salinity-normalized DIC in the near-shore southern region of the PAL-LTER sampling grid was up to $177 \mu \mathrm{mol} \mathrm{kg}{ }^{-1}$ lower than elsewhere, suggesting that near-shore phytoplankton blooms balanced out the negative effect of freshwater on $\Omega_{\text {arag }}$ and even increased $\Omega_{\text {arag }}$ by up to 2 units. In 2005 , when the abovedescribed pattern was particularly conspicuous, high Chl $a$ (up to $20 \mu \mathrm{g} \mathrm{L}^{-1}$ ) in the southern coastal area of the sampling grid provides further evidence that high primary productivity led to the observed high $\Omega_{\text {arag }}$ despite the presence of freshwater. Similar results were found after the calving event of the Mertz Glacier tongue in eastern Antarctica, where enhanced primary productivity increased the $\Omega_{\text {arag }}$ and thereby counteracted the effect of dilution by meltwater input (Shadwick et al., 2013).

Our findings of onshore-offshore and latitudinal gradients of carbon parameters are supported by previous results that suggest similar patterns for several physical and biogeochemical parameters. Summertime surface temperature, salinity, and $\mathrm{NO}_{3}^{-}+\mathrm{NO}_{2}^{-}$are generally lower close to the coast, while Chl $a$, primary production, $\mathrm{Si}(\mathrm{OH})_{2}$, and water column stability decrease from the coast toward the open ocean (Smith, 2001; Garibotti et al., 2003; Vernet et al., 2008). The freshwater along the coast may originate, to a large part, from melting of glacial ice and snow (Meredith et al., 2013). Such glacial and snow-melt plumes have been correlated with increased primary production due to a stabilization of the mixed layer, which creates favorable conditions for phytoplankton blooms (Dierssen et al., 2002). This in turn is thought to be the dominant control of the onshoreoffshore gradient of phytoplankton variability and associated biologically impacted parameters. The north-south gradients possibly reflect the timing of phytoplankton blooms in the north and south. As such, blooms in the north occur sooner than blooms in the south (Smith et al., 2008) - thus on average the PAL-LTER January cruise takes place after the bloom in the north, and during the blooms in the south. This may also be the reason for the nutrient depletion along the coast, despite low biological productivity at the time of sampling in the north (Fig. $4 \mathrm{~h}$ and i). However, it is important to note that, as a result of changes in ice cover, cloud formation, and wind over the past 30 years, biological productivity has increased in the southern part of the WAP and significantly decreased north of $63^{\circ} \mathrm{S}$ (Montes-Hugo et al., 2009). The observed DIC drawdown in the winter water (Figs. 5 and A3) may be a result of biological productivity, which is supported by previous observations of Chl $a$ maxima in the euphotic part of the winter water, likely due to increased iron concentrations there (Garibotti et al., 2003; Garibotti, 2005). However, it is also possible that lateral advection or vertical mixing of lowDIC water into the winter water has contributed to this signal.

Low $\Omega_{\text {arag }}$ values $(<1.35)$ observed offshore coincided with surface waters supersaturated with regard to atmospheric $\mathrm{CO}_{2}$, salinities $>33.5$, and temperatures between 1.3 and $1.5^{\circ} \mathrm{C}$ (not shown). These physical properties are associated with modified UCDW, a mixture between UCDW and Antarctic Surface Water (Smith et al., 1999), and indicate that upwelling of DIC- and TA-rich water into the mixed layer may lead to lower $\Omega_{\text {arag }}$ conditions offshore (Carrillo et al., 2004).

The PAL-LTER data indicate $\mathrm{N}: \mathrm{P}$ uptake ratios lower than the Redfield ratio of $16: 1$, and uptake ratios similar to our findings (14:1) are common for the polar region of the Southern Ocean (Weber and Deutsch, 2010; Martiny et al., 2013). Our observed low ratio may be the result of a high abundance of diatoms with low N / P ratios in this cold and nutrient-rich environment (Arrigo, 1999; Arrigo, 2002; Green and Sambrotto, 2006; Martiny et al., 2013). Rubin et al. (1998) observed a similar N/P ratio of $13.0 \pm 1.2$ 
Table 3. Trend analysis (1999-2013) of Lamont-Doherty Earth Observatory of Columbia University (LDEO) surface continuous underway $p \mathrm{CO}_{2}$ ( $\left.\mu \mathrm{atm}\right)$, salinity, and temperature $\left({ }^{\circ} \mathrm{C}\right)$ measurements from within the central subregion of the Palmer-Long Term Ecological Research (PAL-LTER) sampling grid (Fig. 1, red box). Regression statistics include mean rate, standard error (SE), number of measurements (NM), number of years (NY), $r$-squared, and $p$ value. Trends with a $p$ value $<0.05$ would be considered statistically significant at the $95 \%$ confidence level.

\begin{tabular}{llrrrrr}
\hline Parameter & Season & Rate $\pm \mathrm{SE}$ & $\mathrm{NM}$ & $\mathrm{NY}$ & $r^{2}$ & $p$ value \\
\hline$p \mathrm{CO}_{2}\left(\mu \mathrm{atm} \mathrm{yr}^{-1}\right)$ & Summer & $1.45 \pm 2.97$ & 94774 & 12 & 0.01 & 0.6361 \\
& Fall & $1.90 \pm 0.95$ & 42655 & 14 & 0.26 & 0.0685 \\
& Winter & $0.43 \pm 0.77$ & 26314 & 11 & 0.04 & 0.6304 \\
& Spring & $1.22 \pm 2.72$ & 14813 & 9 & 0.03 & 0.6678 \\
Temperature $\left({ }^{\circ} \mathrm{C} \mathrm{yr}^{-1}\right)$ & Summer & $0.03 \pm 0.05$ & 94774 & 13 & 0.03 & 0.5515 \\
& Fall & $0.00 \pm 0.05$ & 42655 & 14 & 0.01 & 0.9279 \\
& Winter & $0.00 \pm 0.04$ & 26314 & 13 & 0.00 & 0.9262 \\
Salinity $\left(\mathrm{yr}^{-1}\right)$ & Spring & $0.01 \pm 0.03$ & 14813 & 9 & 0.04 & 0.8598 \\
& Summer & $-0.02 \pm 0.02$ & 53713 & 12 & 0.10 & 0.3294 \\
& Fall & $0.02 \pm 0.01$ & 55823 & 13 & 0.14 & 0.0988 \\
& Winter & $-0.01 \pm 0.01$ & 28063 & 10 & 0.01 & 0.6631 \\
& Spring & $-0.01 \pm 0.01$ & 53713 & 11 & 0.05 & 0.1422 \\
\hline
\end{tabular}

in the mixed layer south of the polar front, and an even lower $\mathrm{N} / \mathrm{P}$ ratio of $11.3 \pm 0.3$ was observed in the ironspiked mixed layer during the iron fertilization experiment in the Subantarctic South Pacific (Hales and Takahashi, 2012). Consistent with the low $\mathrm{N} / \mathrm{P}$ ratio, the observed $\mathrm{C}: \mathrm{P}$ ratio $(80.5 \pm 2.5$, corrected for gas exchange) was also lower than the classic Redfield ratio. This indicates that the regional phosphate cycle shows non-Redfield behavior, which is in agreement with the observed $\mathrm{C}: \mathrm{P}$ ratio of $91.4 \pm 7.9$ in the mixed layer south of the polar front (Rubin et al., 1998). For the same region, Rubin et al. (1998) describe Redfield behavior of $\mathrm{C} / \mathrm{N}$ nutrient utilization, which corresponds with our gas-exchange-corrected $\mathrm{C} / \mathrm{N}$ nutrient utilization ratio of $6.7 \pm 0.2$. Recently published work suggests that $\mathrm{C} / \mathrm{N} / \mathrm{P}$ ratios exhibit a latitudinal pattern, with a range of $66: 11: 1$ to $74: 13: 1$ at higher latitudes in the Southern Ocean (Martiny et al., 2013) and can therefore be significantly lower than what we found in this study.

TA variability was largely driven by dilution through freshwater input and mixing (Fig. 5), which is well characterized by the salinity-derived TA relationship presented in Sect. 3.4. However, biological mechanisms such as photosynthesis, respiration, $\mathrm{CaCO}_{3}$ precipitation, and dissolution also played an important role in controlling TA concentrations in the water column and at the surface (Fig. 6). Neglecting these important drivers may be responsible for the large RMSE of our predicted TA (Fig. A2) relative to other studies that either had additional parameters at hand (i.e., $\mathrm{O}_{2}$ or nutrients) to derive inorganic carbon system parameters in coastal environments (Juranek et al., 2009; Kim et al., 2010; Evans et al., 2013) or used salinity algorithms to predict TA in open-ocean regions (Takahashi et al., 2014). Furthermore, TA varied by more than $70 \mu \mathrm{mol} \mathrm{kg} \mathrm{kg}^{-1}$ at salinities $>33.7$, which led to an unbalanced distribution of residuals
(Fig. A2c). Increasing TA at higher salinities and nearly constant DIC concentrations has been observed before in Arctic and Antarctic regions (Dieckmann et al., 2008; Fransson et al., 2011; Rysgaard et al., 2012; Shadwick et al., 2014; Legge et al., 2015) and may be due to formation of ikaite crystals $\left(\mathrm{CaCO}_{3} 6 \mathrm{H}_{2} \mathrm{O}\right.$; Suess et al., 1982) that store TA in sea ice and, upon melting, release the excess TA into the surface water (Rysgaard et al., 2012, 2013). However, reasons for the observed increasing TA at higher salinities along the WAP remain speculative, since direct evidence of ikaite formation/dissolution such as an increase in DIC associated with TA increase is missing (Fig. 6). A combination of other mechanisms, such as upwelling of high-salinity, high-TA waters concomitant with biological DIC drawdown, could have increased TA : DIC ratios at high salinities. Finally, the WAP region is very dynamic, with large seasonal changes that may affect the carbon system in ways not representable by one algorithm and may therefore require seasonally adjusted algorithms.

Despite the above-described shortcomings in our salinityderived TA algorithm, the estimated $\Omega_{\text {arag values give a use- }}$ ful overview of the seasonal distribution and variability in $\Omega_{\text {arag }}$ (Fig. 8). Error propagation of $p \mathrm{CO}_{2}$ measurement precision and TA prediction accuracy suggests that the predicted error for $\Omega_{\text {arag }}$ may be as little as 0.02 (Glover et al., 2011). The seasonal estimations of $\Omega_{\text {arag }}$ suggest that some winter and springtime $\Omega_{\text {arag }}$ values were near $\Omega_{\text {arag }}=1$ and $20 \%$ were between 1.0 and 1.2 (Fig. 8). Short-term exposure to low levels of $\Omega_{\text {arag }}$ may cause severe dissolution of live pteropod shells and has already been observed in the Scotia Sea (Bednaršek et al., 2012). Surface aragonite undersaturation along the WAP may be a result of ocean acidification and may not have been common during preindustrial times (Hauri et al., 2015). 
The large uncertainties in our estimated temporal trends are caused inherently by the large spatial and temporal variability in our data. Nevertheless, our mean rates of $1.45 \pm 2.97$ for summer and $0.43 \pm 0.77 \mu a \mathrm{a} \mathrm{yr}^{-1}$ for winter suggest that the surface water $p \mathrm{CO}_{2}$ has been increasing at a slower rate than the atmospheric $p \mathrm{CO}_{2}$ rate of about $1.9 \mu \mathrm{atm} \mathrm{yr}^{-1}$, and that the air-sea $\mathrm{CO}_{2}$ driving potential has been increasing. Our results may be compared with the recent analysis of the 2002-2015 time-series data obtained across the Drake Passage by Munro et al. (2015). In the waters south of the polar front (their Zone 4, closest to the LTER area), they observed that the surface water $p \mathrm{CO}_{2}$ increased at a rate of $1.30 \pm 0.85 \mu \mathrm{atm} \mathrm{yr}^{-1}$ in summer and $0.67 \pm 0.39 \mu \mathrm{atm} \mathrm{yr}^{-1}$ in winter, which are comparable with ours along the WAP. We observed the strongest but still statistically insignificant increase in surface $p \mathrm{CO}_{2}$ in fall

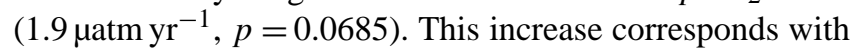
the mean atmospheric $p \mathrm{CO}_{2}$ increase of $1.9 \mu$ atm per year, which causes a pHT decrease of about 0.02 per decade (Takahashi et al., 2014). Interestingly, Stammerjohn et al. (2008a, b) found that sea-ice extent and wind are also changing most rapidly in spring and fall, which may enhance sea-air gas exchange and therefore facilitate positive $p \mathrm{CO}_{2}$ trends. Furthermore, it is likely that the strong counter-effect of biological productivity successfully masks the $p \mathrm{CO}_{2}$ trend in summer, and decreased gas exchange due to sea ice weakens the trend in winter. However, the WAP climate and oceanography are regulated by large-scale atmospheric patterns, such as El Niño-Southern Oscillation and Southern Annular Mode (Stammerjohn et al., 2008a), which may also influence the region's inorganic carbon chemistry on an interannual scale. A longer measurement period may be needed in order to be able to distinguish with certainty between natural variability and secular trends (Henson et al., 2010).

\section{Conclusions}

This study gives new insights into the spatial and temporal variability in the WAP inorganic carbon system and its main physical and biological drivers. In particular, we found that large inorganic carbon drawdown through biological production in summer caused high near-shore $\Omega_{\text {arag }}$, despite glacial and sea-ice meltwater input. Furthermore, the data do not show a significant long-term trend in any of the inorganic carbon chemistry variables measured. Continuation and expansion of the inorganic carbon chemistry time series across other seasons is necessary to distinguish between natural variability and secular trends and to better understand synergistic effects of ocean acidification and climate change. Due to the region's physical complexity of circulation and forcing, and strong dynamic response to climate variability, we recommend development of a highly resolved biogeochemical model to complement our observational work. Implementation of modeling studies will improve our mechanistic understanding of how interannual variability and anthropogenic climate change impact the inorganic carbon chemistry along the WAP, which is imperative to predict the potential impact on the unique WAP ecosystem. 


\section{Appendix A}

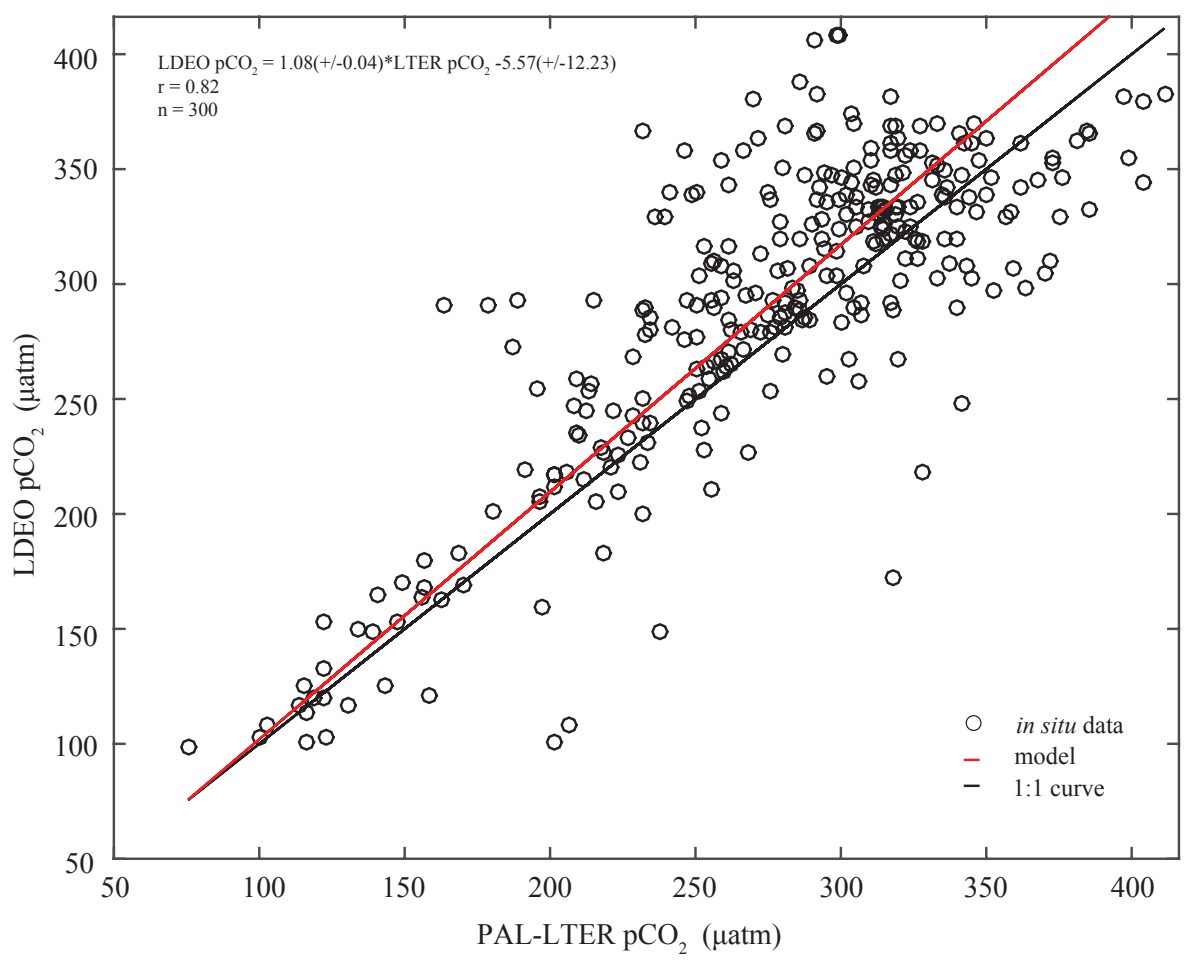

Figure A1. Comparison of Lamont-Doherty Earth Observatory of Columbia University (LDEO) continuous underway $p \mathrm{CO}_{2}$ ( $\mu$ atm) over the Palmer-Long Term Ecological Research (PAL-LTER) sampling grid (Takahashi et al., 2015) with $p \mathrm{CO}_{2}$ ( $\mu$ atm) derived from PAL-LTER dissolved inorganic carbon (DIC, $\mu \mathrm{mol} \mathrm{kg}{ }^{-1}$ ) and total alkalinity (TA, $\mu \mathrm{mol} \mathrm{kg}{ }^{-1}$ ) from discrete samples taken during the same cruise (20052012). PAL-LTER $p \mathrm{CO}_{2}$ outliers that underestimate/overestimate $p \mathrm{CO}_{2}$ relative to the underway observations by more than $150 \mu$ atm were removed. The two data sets were spatially matched, with a $1 \mathrm{~km}$ distance threshold. See Table 1 for statistics. 

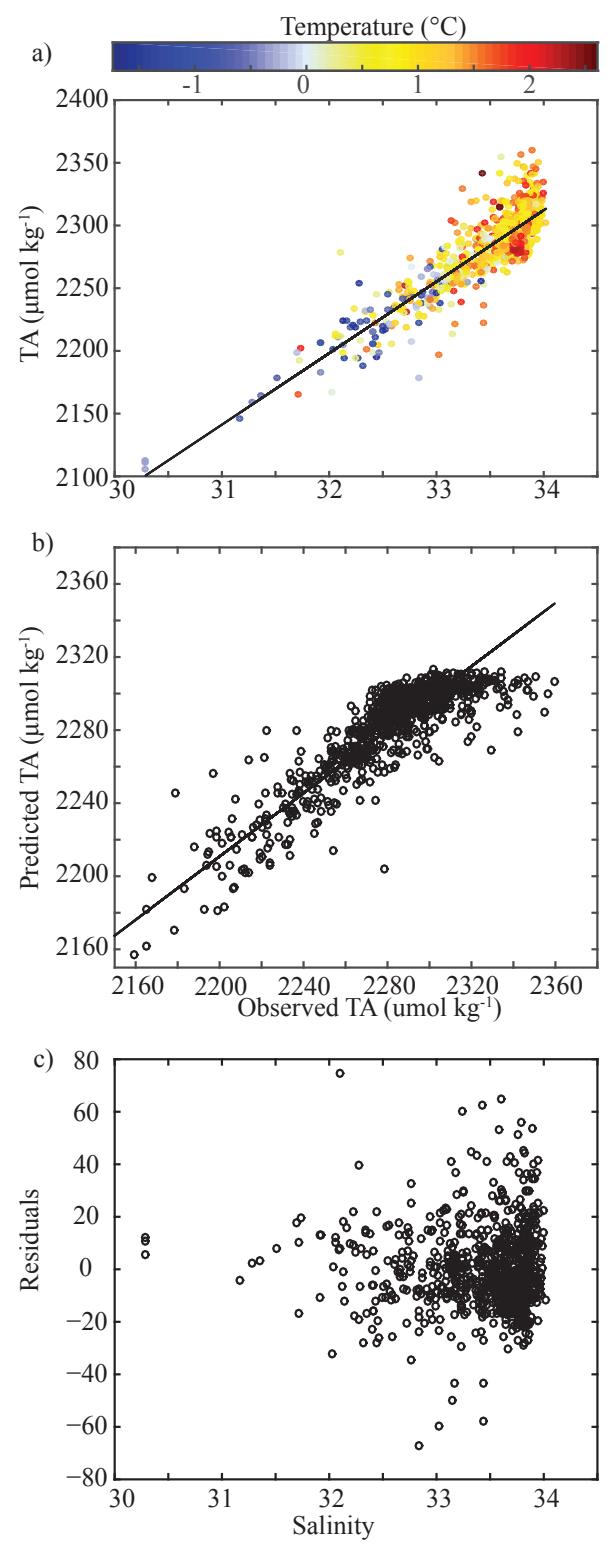

Figure A2. Evaluation of the total alkalinity (TA), $\mu \mathrm{mol} \mathrm{kg}{ }^{-1}$ algorithm. (a) Measured TA as a function of salinity and temperature (color), (b) measured TA vs. predicted TA, and (c) residuals vs. salinity. 

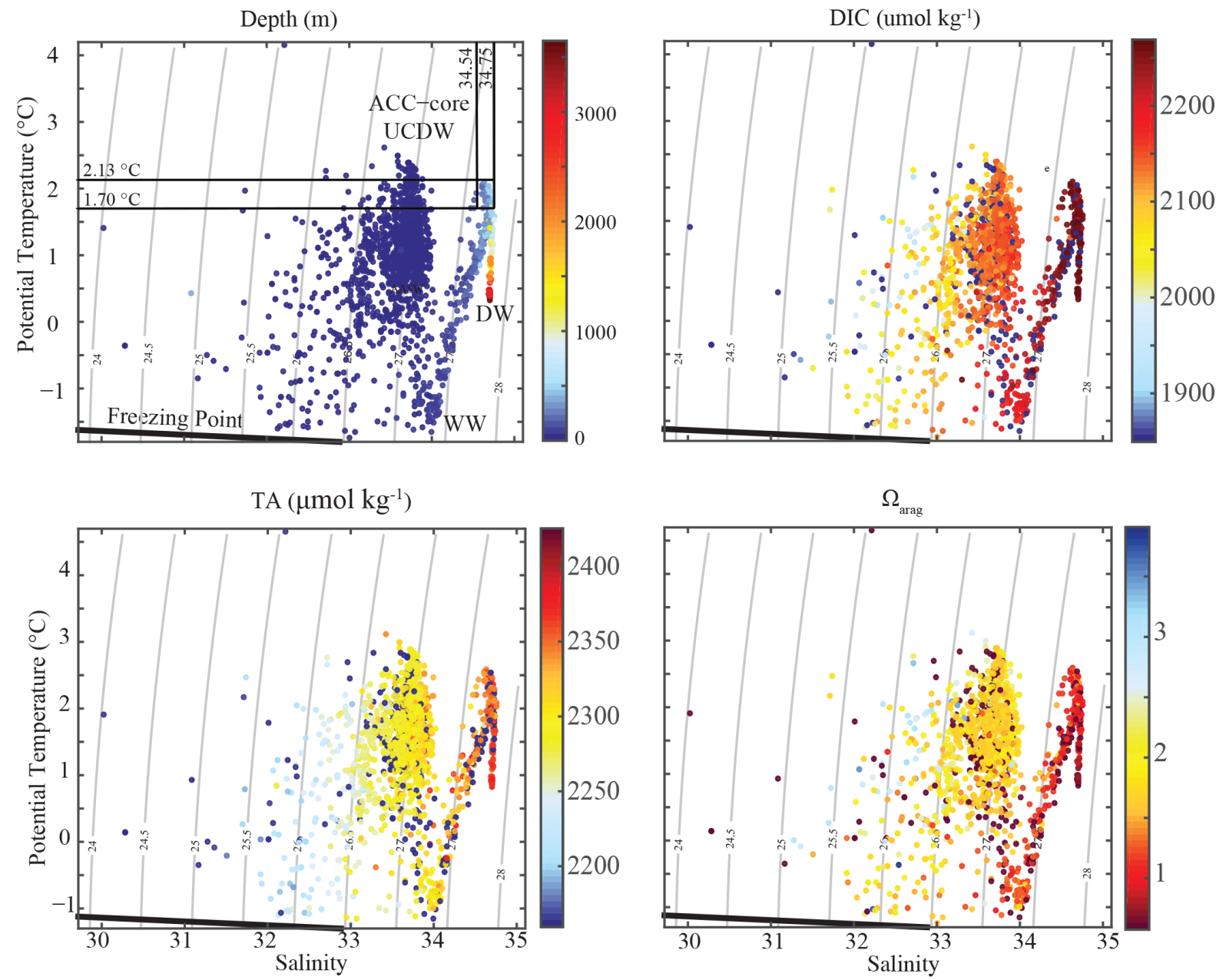

Figure A3. Scatterplots of depth and inorganic carbon chemistry superimposed on potential temperature-salinity diagrams. Shown in color are (a) depth, (b) dissolved inorganic carbon (DIC, $\mu \mathrm{mol} \mathrm{kg}-1$ ), (c) total alkalinity (TA, $\mu \mathrm{mol} \mathrm{kg}{ }^{-1}$ ), and (d) aragonite saturation state $\left(\Omega_{\text {arag }}\right)$. The bold black line illustrates the freezing point as a function of temperature and salinity. Grey lines mark densities. Water masses are indicated and labeled in (a): WW: winter water; AASW: Antarctic Surface Water in summer; ACC-core UCDW: Antarctic Circumpolar Current-core Upper Circumpolar Deep Water; DW: local deep water end member, following Martinson et al. (2008). 
Author contributions. Research design: H. W. Ducklow and T. Takahashi. Field sampling and analytical measurements: T. Takahashi, H. W. Ducklow and M. Erickson. Data analysis and interpretation: C. Hauri with help from all co-authors. Writing: C. Hauri with help from S. C. Doney, T. Takahashi, and H. W. Ducklow.

Acknowledgements. We thank past and present members of the Palmer LTER program as well as the captains and crew of the US Antarctic research vessels. We are especially grateful to Richard Iannuzzi and James Conners for their support with data management, and to Tim Newberger for underway $p \mathrm{CO}_{2}$ measurements. We gladly acknowledge support from the National Science Foundation Polar Programs (NSF OPP-90-11927, OPP-96-32763, OPP-02-17282, OPP-08-23101, and PLR-1440435). T. Takahashi and the Ship of Opportunity Observation Program (SOOP) were supported by a grant (NA10OAR4320143) from the United States NOAA. This is International Pacific Research Center contribution number 1117 .

Edited by: G. Herndl

\section{References}

Anderson, S. P., Drever, J. I., Frost, C. D., and Holden P.: Chemical weathering in the foreland of a retreating glacier, Geochim. Cosmochim. Ac., 64, 1173-1189, doi:10.1016/S00167037(99)00358-0, 2000.

Arrigo, K. R.: Phytoplankton community structure and the drawdown of nutrients and $\mathrm{CO}_{2}$ in the Southern Ocean, Science, 283, 365-367, doi:10.1126/science.283.5400.365, 1999.

Arrigo, K. R.: Taxon-specific differences in C/P and N/P drawdown for phytoplankton in the Ross Sea, Antarctica, Geophys. Res. Lett., 29, 1938, doi:10.1029/2002GL015277, 2002.

Arrigo, K. R., van Dijken, G., and Pabi, S.: Impact of a shrinking Arctic ice cover on marine primary production, Geophys. Res. Lett., 35, L19603, doi:10.1029/2008GL035028, 2008.

Bednaršek, N., Tarling, G. A., Bakker, D. C. E., Fielding, S., Jones, E. M., Venables, H. J., Ward, P., Kuzirian, A., Lézé, B., Feely, R. A., and Murphy, E. J.: Extensive dissolution of live pteropods in the Southern Ocean, Nat. Geosci., 5, 881-885, doi:10.1038/ngeo1635, 2012.

Bopp, L., Resplandy, L., Orr, J. C., Doney, S. C., Dunne, J. P., Gehlen, M., Halloran, P., Heinze, C., Ilyina, T., Séférian, R., Tjiputra, J., and Vichi, M.: Multiple stressors of ocean ecosystems in the 21st century: projections with CMIP5 models, Biogeosciences, 10, 6225-6245, doi:10.5194/bg-10-6225-2013, 2013.

Breiman, L.: Stacked regressions, Mach. Learn., 24, 49-64, doi:10.1007/BF00117832, 1996.

Burnham, K. P. and Anderson, D. R.: Model selection and multimodel inference: A practical information-theoretic approach, Springer Verlag, New York, 2002.

Carrillo, C. J. and Karl, D. M.: Dissolved inorganic carbon pool dynamics in northern Gerlache Strait, Antarctica, J. Geophys. Res., 104, 15873, doi:10.1029/1999JC900110, 1999.

Carrillo, C. J., Smith, R. C., and Karl, D. M.: Processes regulating oxygen and carbon dioxide in surface waters west of the Antarctic Peninsula, Mar. Chem., 84, 161-179, doi:10.1016/j.marchem.2003.07.004, 2004.

Dickson, A. G.: Thermodynamics of the dissociation of boric acid in synthetic seawater from 273.15 to $318.15 \mathrm{~K}$, Deep-Sea Res. Pt. I, 37, 755-766, doi:10.1016/0198-0149(90)90004-F, 1990.

Dickson, A. G. and Goyet, C.: Handbook of methods for the analysis of the various parameters of the carbon dioxide system in sea water, Version 2. No. ORNL/CDIAC-74, Oak Ridge National Lab., TN (United States), 1994.

Dickson, A. G. and Millero, F. J.: A comparison of the equilibrium constants for the dissociation of carbonic acid in seawater media, Deep-Sea Res. Pt. I, 34, 1733-1743, doi:10.1016/01980149(87)90021-5, 1987

Dieckmann, G. S., Nehrke, G., Papadimitriou, S., Göttlicher, J., Steininger, R., Kennedy, H., Wolf-Gladrow, D., and Thomas, D. N.: Calcium carbonate as ikaite crystals in Antarctic sea ice, Geophys. Res. Lett., 35, L08501, doi:10.1029/2008GL033540, 2008.

Dierssen, H. M., Smith, R. C., and Vernet, M.: Glacial meltwater dynamics in coastal waters west of the Antarctic peninsula, P. Natl. Acad. Sci. USA, 99, 1790-5, doi:10.1073/pnas.032206999, 2002.

Dinniman, M. S. and Klinck, J. M.: A model study of circulation and cross-shelf exchange on the west Antarctic Peninsula continental shelf, Deep-Sea Res. Pt. II, 51, 2003-2022, 2004.

Dinniman, M. S., Klinck, J. M., and Smith Jr., W. O.: A model study of Circumpolar Deep Water on the West Antarctic Peninsula and Ross Sea continental shelves, Deep-Sea Res. Pt. II, 58, 1508$1523,2011$.

Ducklow, H. W., Fraser, W. R., Meredith, M. P., Stammerjohn, S. E., Doney, S. C., Martinson, D. G., Sailley, S. F., Schofield, O. M., Steinberg, D. K., Venables, H. J., and Amsler, C. D.: West Antarctic Peninsula: An ice-dependent coastal marine ecosystem in transition, Oceanography, 26, 190-203, doi:10.5670/oceanog.2013.62, 2013.

Ducklow, H. W., Baker, K., Martinson, D. G., Quetin, L. B., Ross, R. M., Smith, R. C., Stammerjohn, S. E., Vernet, M., and Fraser, W.: Marine pelagic ecosystems: the West Antarctic Peninsula, Philos. Trans. R. Soc. B, 362, 67-94, doi:10.1098/rstb.2006.1955, 2007.

Ducklow, H., Clarke, A., Dickhut, R., Doney, S. C., Geisz, H. N., Huang, K, Martinson, D. G., Meredith, M. P., Moeller, H. V., Montes-Hugo, M., Schofield, O., Stammerjohn, S. E., Steinberg, D., and Frazer, W.: The marine ecosystem of the West Antarctic Peninsula, in: Antarctica: An Extreme Environment in a Changing World, edited by: Rogers, A., Johnston, N., Clarke, A., and Murphy, E., Blackwell, 121-159 2012.

Evans, W., Mathis, J. T., Winsor, P., Statscewich, H., and Whitledge, T. E.: A regression modeling approach for studying carbonate system variability in the northern Gulf of Alaska, J. Geophys. Res.-Oceans, 118, 476-489, doi:10.1029/2012JC008246, 2013.

Fransson, A., Chierici, M., Yager, P. L., and Smith, W. O.: Antarctic sea ice carbon dioxide system and controls, J. Geophys. Res., 116, C12035, doi:10.1029/2010JC006844, 2011.

Garibotti, I., Vernet, M., Ferrario, M., Smith, R., Ross, R., and Quetin, L.: Phytoplankton spatial distribution patterns along the western Antarctic Peninsula (Southern Ocean), Mar. Ecol.-Prog. Ser., 261, 21-39, doi:10.3354/meps261021, 2003.

Garibotti, I. A.: Interannual variability in the distribution of the phytoplankton standing stock across the seasonal sea-ice zone 
west of the Antarctic Peninsula, J. Plankton Res., 27, 825-843, doi:10.1093/plankt/fbi056, 2005.

Garibotti, I. A., Vernet, M., and Ferrario, M. E.: Annually recurrent phytoplanktonic assemblages during summer in the seasonal ice zone west of the Antarctic Peninsula (Southern Ocean), DeepSea Res. Pt. I, 52, 1823-1841, doi:10.1016/j.dsr.2005.05.003, 2005.

Glover, D. M., Jenkins, W. J., and Doney, S. C.: Modeling methods for marine science, 1st ed., Cambridge University Press, New York, 2011.

Goldman, J. and Brewer, P. G.: Effect of nitrogen source and growth rate on phytoplankton-mediated changes in alkalinity, Limnol. Oceanogr., 25, 352-357, doi:10.4319/lo.1980.25.2.0352, 1980.

Green, S. E. and Sambrotto, R. N.: Plankton community structure and export of $\mathrm{C}, \mathrm{N}, \mathrm{P}$ and $\mathrm{Si}$ in the Antarctic Circumpolar Current, Deep-Sea Res. Pt. II, 53, 620-643, doi:10.1016/j.dsr2.2006.01.022, 2006.

Hales, B. and Takahashi, T.: Mesoscale biogeochemical responses to iron fertilization in the upper layers of the Southern Ocean Iron Experiment areas, J. Geophys. Res., 117, C01018, doi:10.1029/2011JC006956, 2012.

Hauri, C., Friedrich, T., and Timmermann, A.: Abrupt onset and prolongation of aragonite undersaturation events in the Southern Ocean, Nature Climate Change, doi:10.1038/nclimate2844, 2015

Henson, S. A., Sarmiento, J. L., Dunne, J. P., Bopp, L., Lima, I., Doney, S. C., John, J., and Beaulieu, C.: Detection of anthropogenic climate change in satellite records of ocean chlorophyll and productivity, Biogeosciences, 7, 621-640, doi:10.5194/bg-7621-2010, 2010.

Hofmann, E. E., Klinck, J. M., Lascara, C. M., and Smith, D. A.: Water mass distribution and circulation west of the Antarctic Peninsula and including Bransfield Strait, in: Foundations for Ecological Research West of the Antarctic Peninsula, edited by: Ross, R. M., Hofmann, E. E., and Quetin, L. B., Antarctic Research Series, vol. 70, American Geophysical Union, Washington, DC, 61-80, 1996.

Johnson, K. M., Sieburth, J. M., Williams, P. J. B., and Brändström, L.: Coulometric total carbon dioxide analysis for marine studies: Automation and calibration, Mar. Chem., 21, 117-133, doi:10.1016/0304-4203(87)90033-8, 1987.

Juranek, L. W., Feely, R. A., Peterson, W. T., Alin, S. R., Hales, B., Lee, K., Sabine, C. L., and Peterson, J.: A novel method for determination of aragonite saturation state on the continental shelf of central Oregon using multi-parameter relationships with hydrographic data, Geophys. Res. Lett., 36, L24601, doi:10.1029/2009GL040778, 2009.

Kim, T. W., Lee, K., Feely, R. A., Sabine, C. L., Chen, C. T. A., Jeong, H. J., and Kim, K. Y.: Prediction of Sea of Japan (East Sea) acidification over the past 40 years using a multiparameter regression model, Global Biogeochem. Cy., 24, GB3005, doi:10.1029/2009GB003637, 2010.

Kwok, R.: Spatial patterns of variability in Antarctic surface temperature: Connections to the Southern Hemisphere Annular Mode and the Southern Oscillation, Geophys. Res. Lett., 29, 1705, doi:10.1029/2002GL015415, 2002.

Legge, O. J., Bakker, D. C. E., Johnson, M. T., Meredith, M. P., Venables, H. J., Brown, P. J., and Lee, G. A.: The seasonal cycle of ocean-atmosphere $\mathrm{CO}_{2}$ flux in Ryder Bay, west Antarctic Peninsula, Geophys. Res. Lett., 42, 2934-2942, doi:10.1002/2015GL063796, 2015.

Martinson, D. G., Stammerjohn, S. E., Iannuzzi, R. A., Smith, R. C., and Vernet, M.: Western Antarctic Peninsula physical oceanography and spatio-temporal variability, Deep-Sea Res. Pt. II, 55, 1964-1987, doi:10.1016/j.dsr2.2008.04.038, 2008.

Martinson D. G. and McKee D. C.: Transport of warm Upper Circumpolar Deep Water onto the western Antarctic Peninsula continental shelf, Ocean Science, 8, 433-442, 2012.

Martiny, A. C., Pham, C. T. A., Primeau, F. W., Vrugt, J. A., Moore, J. K., Levin, S. A., and Lomas, M. W.: Strong latitudinal patterns in the elemental ratios of marine plankton and organic matter, Nat. Geosci., 6, 279-283, doi:10.1038/ngeo1757, 2012.

McNeil, B. I. and Matear, R. J.: Southern Ocean acidification: a tipping point at 450-ppm atmospheric $\mathrm{CO}_{2}$, P. Natl. Acad. Sci. USA, 105, 18860-18864, doi:10.1073/pnas.0806318105, 2008.

Mehrbach, C., Culberson, C. H., Hawley, J. E., and Pytkowicz, R. M.: Measurement of the apparent dissociation constants of carbonic acid in seawater at atmospheric pressure, Limnol. Oceanogr., 18, 897-907, doi:10.4319/lo.1973.18.6.0897, 1973.

Meredith, M. P., Venables, H. J., Clarke, A., Ducklow, H. W., Erickson, M., Leng, M. J., Lenaerts, J. T. M., and van den Broeke, M. R.: The Freshwater System West of the Antarctic Peninsula: Spatial and Temporal Changes, J. Clim., 26, 1669-1684, doi:10.1175/JCLI-D-12-00246.1, 2013.

Montes-Hugo, M., Doney, S. C., Ducklow, H. W., Fraser, W., Martinson, D., Stammerjohn, S. E., and Schofield, O.: Recent changes in phytoplankton communities associated with rapid regional climate change along the western Antarctic Peninsula, Science, 323, 1470-1473, doi:10.1126/science.1164533, 2009.

Montes-Hugo, M., Sweeney, C., Doney, S. C., Ducklow, H. W., Frouin, R., Martinson, D. G., Stammerjohn, S. E., and Schofield, O.: Seasonal forcing of summer dissolved inorganic carbon and chlorophyll a on the western shelf of the Antarctic Peninsula, J. Geophys. Res., 115, C03024, doi:10.1029/2009JC005267, 2010.

Munro, D. R., Lovenduski, N. S., Takahashi, T., Stephens, B. B., Newberger, T., and Sweeney, C.: Recent evidence for a strengthening $\mathrm{CO}_{2}$ sink in the Southern Ocean from carbonate system measurements in the Drake Passage (2002-2015), Geophys. Res. Lett., 42, 7623-7630, doi:10.1002/2015GL065194, 2015.

Redfield, A.: The biological control of chemical factors in the environment, Am. Sci., 3, 205-221, 1958.

Rubin, S. I., Takahashi, T., Chipman, D. W., and Goddard, J. G.: Primary productivity and nutrient utilization ratios in the $\mathrm{Pa}$ cific sector of the Southern Ocean based on seasonal changes in seawater chemistry, Deep-Sea Res. Pt. I, 45, 1211-1234, doi:10.1016/S0967-0637(98)00021-1, 1998.

Rysgaard, S., Glud, R. N., Lennert, K., Cooper, M., Halden, N., Leakey, R. J. G., Hawthorne, F. C., and Barber, D.: Ikaite crystals in melting sea ice - implications for $p \mathrm{CO}_{2}$ and $\mathrm{pH}$ levels in Arctic surface waters, The Cryosphere, 6, 901-908, doi:10.5194/tc6-901-2012, 2012.

Rysgaard, S., Søgaard, D. H., Cooper, M., Pucko, M., Lennert, K., Papakyriakou, T. N., Wang, F., Geilfus, N. X., Glud, R. N., Ehn, J., McGinnis, D. F., Attard, K., Sievers, J., Deming, J. W., and Barber, D.: Ikaite crystal distribution in winter sea ice and implications for $\mathrm{CO}_{2}$ system dynamics, The Cryosphere, 7, 707-718, doi:10.5194/tc-7-707-2013, 2013. 
Saba, G. K., Fraser, W. R., Saba, V. S., Iannuzzi, R. A., Coleman, K. E., Doney, S. C., Ducklow, H. W., Martinson, D. G., Miles, T. N., Patterson-Fraser, D. L., Stammerjohn, S. E., Steinberg, D. K., Schofield, O. M.: Winter and spring controls on the summer food web of the coastal West Antarctic Peninsula, Nat. Commun., 5, 4318, doi:10.1038/ncomms5318, 2014.

Sarmiento, J. L., and Gruber, N.: Ocean Biogeochemical Dynamics, Princeton University Press, Princeton, NJ, 528 pp., 2006.

Schofield, O., Ducklow, H. W., Martinson, D. G., Meredith, M. P., Moline, M. A., and Fraser, W. R.: How do polar marine ecosystems respond to rapid climate change?, Science, 328, 1520-1523, doi:10.1126/science.1185779, 2010.

Serebrennikova, Y. M. and Fanning K. A: Nutrients in the Southern Ocean GLOBEC region: variations, water circulation, and cycling, Deep-Sea Res. Pt. II, 51, 1981-2002, 2004.

Shadwick, E. H., Rintoul, S. R., Tilbrook, B. Williams, G. D., Young, N., Fraser, A. D., Marchant, H., Smith, J., and Tamura, T.: Glacier tongue calving reduced dense water formation and enhanced carbon uptake, Geophys. Res. Lett., 40, 904-909, doi:10.1002/grl.50178, 2013.

Shadwick, E. H., Tilbrook, B., and Williams, G. D.: Carbonate chemistry in the Mertz Polynya (East Antarctica): Biological and physical modification of dense water outflows and the export of anthropogenic $\mathrm{CO}_{2}$, J. Geophys. Res.-Oceans, 119, 1-14, doi:10.1002/2013JC009286, 2014.

Smith, D. A., Hofmann, E. E., Klinck, J. M., and Lascara, C. M.: Hydrography and circulation of the West Antarctic Peninsula Continental Shelf, Deep-Sea Res. Pt. I, 46, 925-949, doi:10.1016/S0967-0637(98)00103-4, 1999.

Smith, R. C.: Variability of Primary Production in an Antarctic Marine Ecosystem as Estimated Using a Multi-scale Sampling Strategy, Integr. Comp. Biol., 41, 40-56, doi:10.1093/icb/41.1.40, 2001.

Smith, R. C. and Stammerjohn, S. E.: Variations of surface air temperature and sea-ice extent in the western Antarctic Peninsula region, Ann. Glaciol., 33, 493-500, doi:10.3189/172756401781818662, 2001.

Smith, R. C., Martinson, D. G., Stammerjohn, S. E., Iannuzzi, R. A., and Ireson, K.: Bellingshausen and western Antarctic Peninsula region: Pigment biomass and sea-ice spatial/temporal distributions and interannual variabilty, Deep-Sea Res. Pt. II, 55), 1949-1963, doi:10.1016/j.dsr2.2008.04.027, 2008.

Stammerjohn, S., Massom, R., Rind, D., and Martinson, D.: Regions of rapid sea ice change: An inter-hemispheric seasonal comparison, Geophys. Res. Lett., 39, L06501, doi:10.1029/2012GL050874, 2012.

Stammerjohn, S. E., Martinson, D. G., Smith, R. C., and Iannuzzi, R. A.: Sea ice in the western Antarctic Peninsula region: Spatio-temporal variability from ecological and climate change perspectives, Deep-Sea Res. Pt. II, 55, 2041-2058, doi:10.1016/j.dsr2.2008.04.026, 2008a.

Stammerjohn, S. E., Martinson, D. G., Smith, R. C., Yuan, X., and Rind, D.: Trends in Antarctic annual sea ice retreat and advance and their relation to El Niño-Southern Oscillation and Southern Annular Mode variability, J. Geophys. Res., 113, C03S90, doi:10.1029/2007JC004269, 2008b.

Steinacher, M., Joos, F., Frölicher, T. L., Plattner, G.-K., and Doney, S. C.: Imminent ocean acidification in the Arctic projected with the NCAR global coupled carbon cycle-climate model, Biogeosciences, 6, 515-533, doi:10.5194/bg-6-515-2009, 2009.

Stone, M.: Cross-validatory choice and assessment of statistical predictions, J. R. Stat. Soc., 111-147, 1974.

Suess, E., Balzer, W., Hesse, K. F., Müller, P. J., Ungerer, C. A., and Wefer, G.: Calcium carbonate hexahydrate from organicrich sediments of the antarctic shelf: precursors of glendonites, Science, 216, 1128-1131, doi:10.1126/science.216.4550.1128, 1982.

Takahashi, T., Sutherland, S. C., Wanninkhof, R., Sweeney, C., Feely, R. A., Chipman, D. W., Hales, B., Friederich, G., Chavez, F., Watson, A., Bakker, D. C. E., Schuster, U., Metzl, N., Yoshikawa-Inoue, H., Ishii, M., Midorikawa, T., Nojiri, Y., Sabine, C., Olafsson, J., Arnarson, T. S., Tilbrook, B., Johannessen, T., Olsen, A., Bellerby, R., Körtzinger, A., Steinhoff, T., Hoppema, M., de Baar, H. J. W., Wong, C. S., Delille, B., and Bates, N. R.: Climatological mean and decadal changes in surface ocean $\mathrm{pCO}_{2}$, and net sea-air $\mathrm{CO}_{2}$ flux over the global oceans, Deep-Sea Res. Pt. II, 56, 554-577, doi:10.1016/j.dsr2.2008.12.009, 2009.

Takahashi, T., Sutherland, S. C., Chipman, D. W., Goddard, J. G., Ho, C., Newberger, T., Sweeney, C., and Munro, D. R.: Climatological distributions of $\mathrm{pH}, \mathrm{pCO}_{2}$, total $\mathrm{CO}_{2}$, alkalinity, and $\mathrm{CaCO}_{3}$ saturation in the global surface ocean, and temporal changes at selected locations, Mar. Chem., 164, 95-125, doi:10.1016/j.marchem.2014.06.004, 2014.

Takahashi, T., Sutherland, S. C., and Kozyr, A.: Global Ocean Surface Water Partial Pressure of $\mathrm{CO}_{2}$ Database: Measurements Performed During 1957-2014, ORNL/CDIAC-161, NDP088(V2014), Carbon Dioxide Information Analysis Center, Oak Ridge National Laboratory, U.S. Department of Energy, Oak Ridge, Tennessee, doi:10.3334/CDIAC/OTG.NDP088(V2014), 2015.

Tortell, P. D., Asher, E. C., Ducklow, H. W., Goldman, J. A. L., Dacey, J. W. H., Grzymski, J. J., Young, J. N., Kranz, S. A., Bernard, K. S., and Morel, F. M. M.: Metabolic balance of coastal Antarctic waters revealed by autonomous $p \mathrm{CO}_{2}$ and $\Delta \mathrm{O}_{2} / \mathrm{Ar}$ measurements, Geophys. Res. Lett., 41, 6803-6810, doi:10.1002/2014GL061266, 2014.

Van Heuven, S., Pierrot, D., Rae, J. W. B., Lewis, E., and Wallace, D. W. R.: MATLAB Program Developed for $\mathrm{CO}_{2}$ System Calculations, 2011.

Vernet, M., Martinson, D., Iannuzzi, R. Stammerjohn, S.E., Kozlowski, W., Sines, K., Smith, R., and Garibotti, I.: Primary production within the sea-ice zone west of the Antarctic Peninsula: I - Sea ice, summer mixed layer, and irradiance, Deep-Sea Res. Pt. II, 55, 2068-2085, doi:10.1016/j.dsr2.2008.05.021, 2008.

Wang, X., Yang, G.-P., López, D., Ferreyra, G., Lemarchand, K., and Xie, H.: Late autumn to spring changes in the inorganic and organic carbon dissolved in the water column at Scholaert Channel, West Antarctica, Antarct. Sci., 22, 145, doi:10.1017/S0954102009990666, 2009.

Weber, T. S. and Deutsch, C.: Ocean nutrient ratios governed by plankton biogeography, Nature, 467, 550-554, doi:10.1038/nature09403, 2010.

Weiss, R.: Carbon dioxide in water and seawater: the solubility of a non-ideal gas, Mar. Chem., 2, 203-215, doi::10.1016/03044203(74)90015-2, 1974. 
Wolf-Gladrow, D. A., Zeebe, R. E., Klaas, C., Körtzinger, A., and Dickson, A. G.: Total alkalinity: The explicit conservative expression and its application to biogeochemical processes, Mar. Chem., 106, 287-300, doi:10.1016/j.marchem.2007.01.006, 2007.

Yamamoto-Kawai, M., McLaughlin, F. A., Carmack, E. C., Nishino, S., and Shimada, K.: Aragonite undersaturation in the Arctic Ocean: effects of ocean acidification and sea ice melt., Science, 326, 1098-1100, doi:10.1126/science.1174190, 2009.
Yuan, X.: ENSO-related impacts on Antarctic sea ice: a synthesis of phenomenon and mechanisms, Antarct. Sci., 16, 415-425, doi:10.1017/S0954102004002238, 2004.

Yuan, X. and Martinson, D. G.: The Antarctic dipole and its predictability, Geophys. Res. Lett., 28, 3609-3612, doi:10.1029/2001GL012969, 2001. 